OPEN ACCESS

Edited by: Kelen Cristina Ribeiro Malmegrim,

University of São Paulo, Brazi

Reviewed by:

João Rodrigues Lima Júnior,

City of Hope National Medical Center,

United States

Ayman Rezk,

University of Pennsylvania,

United States

*Correspondence:

Paolo A. Muraro

p.muraro@imperial.ac.uk orcid.org/0000-0002-3822-1218

Specialty section:

This article was submitted to Alloimmunity and Transplantation,

a section of the journal

Frontiers in Immunology

Received: 12 November 2021 Accepted: 29 December 2021

Published: 01 February 2022

Citation:

Cencioni MT, Genchi A, Brittain G, de Silva TI, Sharrack B, Snowden JA, Alexander $T$, Greco $R$ and Muraro PA

(2022) Immune Reconstitution Following Autologous Hematopoietic

Stem Cell Transplantation for

Multiple Sclerosis: A Review on Behalf of the EBMT Autoimmune

Diseases Working Party.

Front. Immunol. 12:813957. doi: 10.3389/fimmu.2021.813957

\section{Immune Reconstitution Following Autologous Hematopoietic Stem Cell Transplantation for Multiple Sclerosis: A Review on Behalf of the EBMT Autoimmune Diseases Working Party}

Maria Teresa Cencioni ${ }^{1}$, Angela Genchi ${ }^{2}$, Gavin Brittain ${ }^{3,4}$, Thushan I. de Silva ${ }^{3,5}$, Basil Sharrack ${ }^{3,4}$, John Andrew Snowden ${ }^{6,7}$, Tobias Alexander $^{8,9}$, Raffaella Greco $^{10}$ and Paolo A. Muraro ${ }^{1 *}$

\begin{abstract}
'Division of Neurology, Department of Brain Sciences, Imperial College London, London, United Kingdom, ${ }^{2}$ Department of Neurology, Neurology Unit, Istituto di Ricovero e Cura a Carattere Scientifico (IRCCS) San Raffaele Scientific Institute, Vita-Salute San Raffaele University, Milan, Italy, ${ }^{3}$ South Yorkshire Regional Department of Infection and Tropical Medicine, Sheffield Teaching Hospitals National Health Service (NHS) Foundation Trust, Sheffield, United Kingdom, ${ }^{4}$ Institute for Translational Neuroscience and Sheffield Neuroscience Biomedical Research Centre (BRC), Sheffield, United Kingdom, ${ }^{5}$ Department of Infection, Immunity and Cardiovascular Disease, The University of Sheffield, Sheffield, United Kingdom, ${ }^{6}$ Department of Haematology, Sheffield Teaching Hospitals National Health Service (NHS) Foundation Trust, Sheffield, United Kingdom, ${ }^{7}$ Department of Oncology and Metabolism, The University of Sheffield, Sheffield, United Kingdom, ${ }^{8}$ Charite - Universitätsmedizin Berlin, Corporate member of Freie Universität Berlin and Humboldt-Universität zu Berlin, Department of Rheumatology and Clinical Immunology, Berlin, Germany, ${ }^{9}$ Deutsches Rheuma-Forschungszentrum, ein Leibniz Institut, Berlin, Germany, 10 Unit of Haematology and Bone Marrow Transplantation, Istituto di Ricovero e Cura a Carattere Scientifico (IRCCS) San Raffaele Scientific Institute, Vita-Salute San Raffaele University, Milan, Italy
\end{abstract}

Multiple sclerosis (MS) is a central nervous system (CNS) disorder, which is mediated by an abnormal immune response coordinated by $\mathrm{T}$ and $\mathrm{B}$ cells resulting in areas of inflammation, demyelination, and axonal loss. Disease-modifying treatments (DMTs) are available to dampen the inflammatory aggression but are ineffective in many patients. Autologous hematopoietic stem cell transplantation (HSCT) has been used as treatment in patients with a highly active disease, achieving a long-term clinical remission in most. The rationale of the intervention is to eradicate inflammatory autoreactive cells with lymphoablative regimens and restore immune tolerance. Immunological studies have demonstrated that autologous HSCT induces a renewal of TCR repertoires, resurgence of immune regulatory cells, and depletion of proinflammatory $T$ cell subsets, suggesting a "resetting" of immunological memory. Although our understanding of the clinical and immunological effects of autologous HSCT has progressed, further work is required to characterize the mechanisms that underlie treatment efficacy. Considering that memory $\mathrm{B}$ cells are disease-promoting and stem-like T cells are multipotent progenitors involved in self-regeneration of central and effector memory cells, investigating the reconstitution of $B$ cell compartment and stem and effector subsets of immunological memory following 
autologous HSCT could elucidate those mechanisms. Since all subjects need to be optimally protected from vaccine-preventable diseases (including COVID-19), there is a need to ensure that vaccination in subjects undergoing HSCT is effective and safe. Additionally, the study of vaccination in HSCT-treated subjects as a means of evaluating immune responses could further distinguish broad immunosuppression from immune resetting.

Keywords: hematopoietic stem cell (HSC) transplantation, disease-modifying therapies (DMT), immune reconstitution, immunological memory, vaccination

\section{INTRODUCTION}

Multiple sclerosis (MS) is a chronic demyelinating disease of the central nervous system (CNS) characterized by a dysregulation of self-tolerance toward myelin and persistent activation of autoreactive cells (1-3). Infiltration of peripheral self-reactive cells in the CNS and bystander immune activation of microglia and resident macrophages damages the myelin sheaths causing demyelination, axonal transection, chronic inflammation, and over time progressive neuronal damage. Infiltrating cells show a memory and effector memory phenotype with pro-inflammatory and cytotoxic features (4). Effective treatment strategies in MS are mostly based on lympho-depletion or blockade of immune cell recirculation, but the aim of disease remission is not met in every patient; and long-term drug administration results in exposure to risks including progressive multifocal leukoencephalopathy (PML), hypogammaglobulinemia, and autoimmune thrombocytopenia as well as other secondary autoimmune diseases (5). Autologous hematopoietic stem cell transplantation (HSCT) has demonstrated long remission and neurological improvement with acceptable safety for selected patients with highly active, relapsing-remitting MS (RRMS), in which it is currently considered a standard treatment according to EBMT guidelines $(6,7)$. The rationale of HSCT is to remove pathogenic cells with a myelo- or lymphoablative conditioning regimen and allow immune reconstitution from myeloid or lymphoid progenitor cells. Thymus-dependent $\mathrm{T}$ cell regeneration and immune regulation mediated by $\mathrm{T}$ and natural killer (NK) cells constitute the major identified pathways influencing immune reconstitution after HSCT for treatment of autoimmune diseases. The mechanism underlying the long clinical remission post-HSCT remains unknown. Immune memory persistence could be the cause of treatment failure in MS especially in patients with high degree of inflammation. Recent discoveries have pointed out that memory stem cells (Tscm) with a hybrid phenotype of stem cells and effector memory cells contribute to chronic inflammation and tissue damage in autoimmune disorders. In this article, we highlight current knowledge and provide a perspective on studies with potential to advance our understanding of the mechanisms of HSCT as therapy for people with MS. We also discuss how protective immunity following vaccination before and after autologous HSCT can serve as a surrogate marker of immunological memory.

\section{DISEASE-MODIFYING TREATMENTS IN MS}

Disease-modifying therapies (DMTs) for MS have significantly expanded in the last 30 years, posing new challenges for clinicians and patients. The majority of DMTs are used in RRMS, and among second-line and immune-suppressive therapies, we can distinguish between immune-sequestering (natalizumab) and lympho-depleting treatments (rituximab/ ocrelizumab/ofatumumab, alemtuzumab, and cladribine).

Natalizumab (NAT) is a monoclonal antibody which binds the VLA- 4 integrin $\alpha 4$ chain $(C D 49 \mathrm{~d})$, thereby inhibiting leukocyte migration into the CNS and gut parenchyma. NAT efficacy for RRMS has been demonstrated by randomized clinical trials (RCTs) $(8,9)$ and real-world data $(10,11)$. However, NAT therapeutic success has been hampered by the risk of progressive multifocal leukoencephalopathy (PML), a diffuse demyelinating disease caused by polyomavirus reactivation referred to as John Cunningham virus (JCV) (12). The risk of developing PML ranges from 0.09 to 11.1 cases per 1,000 per year (12). While it is reduced with NAT-extended interval dosing (13), concerns persist in undertaking this treatment in JCV-positive patients. Following treatment discontinuation (often due to PML risk), disease reactivation/rebound is observed in up to $27.9 \%$ of patients within 6 months and disability accumulation in 37\% of cases (14).

Rituximab (RTX), a chimeric mouse-human monoclonal antibody, and ocrelizumab (OCR) and ofatumumab (OFA), second-generation humanized monoclonal antibodies, are antiCD20-depleting therapies. Both induce the depletion of a broad range of B cells, sparing plasmablasts and plasma cells, suggesting an antibody-independent mechanism of action. Despite several randomized clinical trials (RCTs) and real-world data demonstrating RTX efficacy (15), only OCR and OFA have been approved for RRMS based on the results of the OPERA I and II studies $(16,17)$. Compared to IFN $\beta-1 \mathrm{a}$, OCR and OFA are associated with a modestly higher risk of infections, mainly respiratory infections, varicella-zoster, and herpes simplex. Moreover, anti-CD20 monoclonal antibodies pose a high risk of HBV-associated hepatitis, liver failure $(18,19)$, and an increased risk of severity of SARS-CoV-2 infection (20). Despite B celldepleting therapies being administered as pulsed infusions every 1-6 months, the related B-cell immunosuppression must be considered chronic, with consequences in terms of cumulative 
adverse events. Therefore, long-term data are required to explore any potential increased rate of malignancies, chronic hypogammaglobulinemia, or infection.

Alemtuzumab (ALEM), a monoclonal antibody against the CD52 surface antigen, induces rapid lymphocyte depletion. The CARE-MS I and II trials demonstrated ALEM efficacy compared with IFN $\beta$-1a in treatment-naive RRMS patients and those who had failed first-line therapies $(21,22)$. The extension studies, with a 5 -year follow-up $(23,24)$, have shown that $68.5 \%$ and $59.8 \%$ of patients required only the two initial courses of ALEM to maintain treatment efficacy, and $>95 \%$ of patients received no other DMTs. A high infection risk has been reported $(67.3 \%$ in CARE-MS I and $76.8 \%$ in CARE-MS II), as well as the development of secondary autoimmune disorders which may be related to the rapid $\mathrm{B}$ cell recovery in absence of $\mathrm{T}$ cell immune regulation (25).

Cladribine (CdA), an oral DMT, is a purine analogue that, when metabolized to its active form, is concentrated in lymphocytes and monocytes while sparing other cells. The phase III CLARITY study showed high efficacy in the treatment of RRMS compared with placebo (26). In the extension study, no additional benefit was observed with four consecutive annual courses of treatments compared to two (26). Nevertheless, postmarketing studies have downsized CdA effectiveness compared to the highly efficacious therapies (27). Severe side effects including risk of myelosuppression, opportunistic infections, nephrotoxicity, and possible increased risk of malignancy were reported (5).

\section{AUTOLOGOUS HSCT AS TREATMENT FOR MS}

\section{Highlights on Outcomes After HSCT in Progressive and Active Relapsing MS}

The clinical experience of HSCT in MS started in 1995 and involved European and North American centers (28). Initially, patients considered suitable for the trials showed high disability, advanced progressing disease, unresponsiveness to conventional treatments, and, in some, disease activity in the year preceding the enrolment, evaluated by clinical deterioration or/and evidence of gadolinium (Gd)-enhanced disease lesions in magnetic resonance imaging (MRI). Results from these studies reported a remarkable reduction or complete abolition of disease activity established by a decreased number of Gd-positive lesions starting immediately after mobilization with cyclophosphamide (Cy) and further declining in the months after conditioning therapy (28-34). The effectiveness of HSCT in progressive MS was estimated by measuring the evolution of disability measured by the Expanded Disability Status Scale (EDSS) and showed a failure of $40 \%$ and $52 \%$ at 3 and 6 years, respectively, with a deterioration of neurological function $(32,35)$, while disease progression-free survival at 15 years was $44 \%$ with active CNS disease pre-transplant and $10 \%$ for those without (36). A retrospective analysis of long-term (median follow-up of 6.6 years) HSCT outcomes in 281 patients $(78 \%$ of them with progressive MS) clearly showed that younger age, relapsing form of MS, fewer prior immunotherapies, and lower baseline EDSS scores were factors associated with better outcomes. Progressive MS (PMS) was associated with neurological progression after transplant compared to relapsing forms of disease (HR, 2.33; 95\% CI, 1.27-4.28) (37). In a prospective phase II clinical trial of HSCT for treatment refractory MS including patients with RRMS (57\%) and with secondary progressive MS (SPMS) (43\%), the event-free survival (EFS), defined as freedom from MS relapses, was 60\% (70\% for RRMS), without evidence of relapse, disability progression, or new MRI lesions, after a median follow-up of 36 months (38). Conclusions can be made that patients with RRMS respond more favorably to HSCT than SPMS even when patients with SPMS have an "active MRI."

In some studies, HSCT was used to treat patients with a diagnosis of "malignant" RRMS, characterized by short duration of disease and recurrent and severe relapses (39-45) with a clear suppression or stabilization of the disease course. Subsequent studies increasingly or exclusively treated with HSCT patients with relapsing-remitting MS (RRMS). One single-center study reported that HSCT in subjects in the early course of RRMS, which failed at least 6 months of interferon- $\beta$; induced a significant EDSS improvement, at 6 and 12 months and 2 and 4 years, $100 \%$ of progression-free survival and $76 \%$ of relapse-free survival (45). Those results indicated that HSCT in patients with active disease removes inflammation and generates a long-term remission, improving neurological condition, potentially stopping or delaying neurodegenerative processes. In a phase 2 trial termed autologous HSCT with high-dose immunosuppressive therapy (HDIT) performed in RRMS (HALT-MS), EFS, absence of new MRI lesions, and neurological worsening in treated participants approached $70 \%$ after a median 62 -month follow-up (41). The individual components of the composite outcome showed $91.3 \%$ of EDSS progression-free survival, $86.9 \%$ of clinical relapse-free survival, and $86.3 \%$ of MRI event-free survival (41).

Studies with long-term follow-up demonstrated a durable remission, and stabilization of a clinical course is sustained long beyond the immunosuppressive effect of chemotherapy, confirming a better outcome in patients with relapsing forms of MS $(37,46)$.

Despite the efficacy of HSCT in MS, it remains associated with a treatment-related mortality risk ranging from none in some clinical trials and reports $(41,47,48)$ to around $0.2 \%(49,50), 1.4 \%(51)$, $2.5 \%$ (52) in larger series up to $4 \%$ in one trial of patients treated with a high intensity myeloablative regimen (46). Overall, there has been reduction in transplant-related mortality (TRM) over time $(51,53)$, probably related to better patient selection and choice of conditioning regimen, which has permitted acceptance within the neurological community. Even with successful treatment, shortand longer-term adverse events are recognized, including infection, herpes virus reactivation (Epstein-Barr virus, cytomegalovirus) (48), secondary autoimmunity (up to $10 \%$ ), endocrinopathy, and late cancers $(54,55)$. However, in the last decade, the safety of the procedure has shown a marked improvement, thanks to a growing experience in selecting the most appropriate patients to transplant, and advances in conditioning and support regimens. According to recent EBMT (56) data, rates of TRM have been falling to around 
$1 \%$ or below, in recent years. The demographics and outcomes from studies of HSCT in MS have been recently reviewed (57).

\section{HSCT Versus DMT}

There are only two available RCTs comparing HSCT to current DMTs in MS, both with methodological limitations. The ASTIMS study compared myeloablative HSCT to mitoxantrone (MTX) in patients with RRMS (33\%) or PMS (67\%) (58). Regardless of disease subtype, the HSCT group demonstrated a significant reduction in new T2 lesions at 4 years, complete suppression of new Gd+ lesions (versus 56\% of MTX patients), and significantly reduced annualized relapse rate ( 0.19 vs. 0.6 for MTX). However, HSCT did not demonstrate EDSS stabilization or improvement: this might be related to the high proportion of progressive patients, known to respond less favorably (59). The MIST study was an open-label trial of 110 RRMS patients, randomized 1:1 to receive non-lymphoablative HSCT or an FDA-approved DMT, based on the treating neurologist's judgment (47). At 5 years, disease progression was remarkably suppressed in the HSCT arm $(9.71 \%$ versus $75.3 \%)$ with similar impressive reductions in relapses (15.4\% versus $85.2 \%$ ). No evidence of disease activity (NEDA), defined as no progression, no relapses, and no new or enlarging lesions on magnetic resonance imaging, was seen in $78.5 \%$ of HSCT patients versus $2.97 \%$ in the DMT arm. Patients in the DMT group who experienced progression despite 1 year of treatment were crossed over $(n=31)$ to HSCT, and significant comparable outcomes to the patients initially randomized to HSCT were seen in EDSS scores and mean T2-weighted lesion volume on MRI. The MIST study has several limitations (1): incomplete follow-up data in the DMT arm, due to treatment crossover, (2) ALEM was excluded from use in the DMT group because of drug-related persistent lymphopenia and autoimmune disorders. OCR, OFA, and CdA were not licensed at the time the study was opened to recruitment. Clinical outcomes from ASTIMS and MIST studies are summarized in Table 1. While waiting for a direct comparison between the efficacy of HSCT and that of approved highly effective DMTs, some information can be cautiously derived by considering the degree of NEDA achieved in clinical trials of HSCT compared with that of other approved DMTs. Comparisons between different RCTs must be made with caution considering different population characteristics and follow-up schedules. A cross-sectional analysis reveals that the proportion of patients for whom NEDA was achieved at 2 years was $7 \%-16 \%$ among those who received placebo, $13 \%-27 \%$ among patients who received IFN $\beta-1 \mathrm{a}$, and $22 \%-48 \%$ among patients who received other active drugs (dimethyl fumarate, fingolimod, NAT, ALEM, OCR); among patients who underwent HSCT, the NEDA proportion was considerably higher, at 70\%$92 \%(60)$. In a retrospective, single-center, real-world study comparing the efficacy and safety of HSCT vs. ALEM in aggressive RRMS patients, HSCT seems to be superior to ALEM in inducing complete disease control (NEDA 75\% versus $56 \% ; \mathrm{p}=0.023$ ) and in promoting short-term disability improvement (61). Available evidence does not allow the identification of patients who would benefit from early aggressive therapy versus an escalation approach. Despite highly effective DMTs providing significant control of disease activity, they carry the risk of serious adverse events. Immunesuppressive DMTs are associated with an increased risk of mild to moderate infections and with reactivation of latent pathogens. The risk of herpesvirus and tuberculous-related diseases is increased with immunosuppressive therapies; similarly, hepatitis $B$ virus $(\mathrm{HBV})$ reactivation is a risk with anti-CD20 DMTs.

\section{Studies of Immune Reconstitution Following Autologous HSCT in MS}

Since 2000, detailed immunological studies have started to examine the immune effects and potential mechanisms of action of autologous HSCT for treatment of autoimmune disease. Focusing on contributions from studies in treated MS patients, we first review here some key results on studies of adaptive and innate immunity. We next identify some important questions and outline future studies that could address them.

TABLE 1 | Selected clinical outcomes from the two randomized controlled trials of HSCT vs. DMT.

\begin{tabular}{|c|c|c|c|c|}
\hline & \multicolumn{2}{|c|}{ ASTIMS $^{a}$} & \multicolumn{2}{|c|}{ MIST study ${ }^{b}$} \\
\hline & $0 \%$ & $56 \%$ & $-32 \%$ & $+34 \%$ \\
\hline Relapses & \multicolumn{2}{|c|}{ Annualized relapse rate^ } & \multicolumn{2}{|c|}{ New relapses^ } \\
\hline & 0.19 & 0.6 & $15 \%$ & $85 \%$ \\
\hline Clinical progression & \multicolumn{2}{|c|}{ Increase in EDSS* } & \multicolumn{2}{|c|}{ 1-point increase in EDSS score^ } \\
\hline
\end{tabular}

${ }^{a}$ Mancardi GL, Sormani MP, Di Gioia M, Vuolo L, Gualandi F, Amato MP, et al. Autologous haematopoietic stem cell transplantation with an intermediate intensity conditioning regimen in multiple sclerosis: the Italian multi-centre experience. Mult Scler. 2012;18(6):835-42.9. ${ }^{b}$ Burt RK, Balabanov R, Burman J, Sharrack B, Snowden JA, Oliveira MC, et al. Effect of Nonmyeloablative Hematopoietic Stem Cell Transplantation vs. Continued Disease-Modifying Therapy on Disease Progression in Patients with Relapsing-Remitting Multiple Sclerosis: A Randomized Clinical Trial. Jama. 2019;321(2):165-74.

DMT, disease-modifying treatment; HSCT, Autologous hematopoietic stem cell transplantation; PMS, progressive MS; EDSS, Expanded Disability Status Scale.

Symbol ${ }^{*}=$ no statistical difference, $\wedge=$ statistical difference. 


\section{Adaptive Immunity T Cells}

In one of the early studies, Muraro et al. showed that $\mathrm{CD}^{+} \mathrm{T}$ cell levels were reported to have recovered at 6 months after highintensity myelo- and immunoablative HSCT with different kinetics of immune reconstitution of $\mathrm{CD}^{+}$and $\mathrm{CD}^{+} \mathrm{T}$ cells (62); $\mathrm{CD}^{+} \mathrm{T}$ cells recovered gradually compared to $\mathrm{CD} 8^{+} \mathrm{T}$ cells, and the CD4/CD8 ratios decreased at 6 months and reached the baseline levels at 1 year (62). The longitudinal analysis of the frequency of T cell subpopulations after HSCT showed a phenotypic renewal of the $\mathrm{T}$ helper cell compartment. In the CD4+ compartment, memory (M) T cells (CD45RA ${ }^{-}$ $\mathrm{CD}_{4} 5 \mathrm{RO}^{+} \mathrm{CD} 27^{+}$) predominate at the baseline and are replaced by naïve $\mathrm{T}$ cells $\left(\mathrm{CD}_{4} \mathrm{RA} \mathrm{C}^{+} \mathrm{CD} 45 \mathrm{RO}^{-} \mathrm{CD} 27^{+}\right)$at 2 years after therapy with a $76 \%$ reduction of $\mathrm{T}_{\mathrm{M}} / \mathrm{T}_{\mathrm{N}}$ ratios (62). The de novo generated $\mathrm{CD}^{+} \mathrm{T}$ cells in the peripheral blood (PB) display features of thymic origin, such as increased co-expression levels of CD31 or T-cell receptor excision circles (TREC). counts and a strong significant correlation of frequency of CD4-naïve T cells and CD4 RTE T cells at the 1- and 2-year follow-up. Analysis of a single T cell receptor (TCR) repertoire at the single clone level by sequencing of TCR $\beta$ transcripts of sorted PB CD4 T cells demonstrated increased repertoire diversity compared to the pre-HSCT (62). The dominant preexistent TCR clones were completely depleted after the conditioning regimens and replaced by clones with a new repertoire (63). Contrary to the CD4 compartment, the CD8+ pool showed an incomplete renewal of clonal specificities with the persistence of preexisting clones (62). The proportion of subpopulations did not change compared to the baseline. The only difference was on effector memory terminally differentiated CD8 $\mathrm{T}$ cells that expressed senescence phenotype CD $28^{-} \mathrm{CD} 57^{+} \mathrm{CD} 95 /$

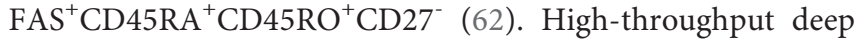
TCR $\beta$ chain sequencing on CD8 T cell clones before and after HSCT showed that the CD8 compartment post-HSCT was predominantly constituted by a selective expansion of dominant preexistent TCR clones (63).

Long-term TCR repertoire reconstitution was examined in matched CSF and PB CD4 and CD8 T cell clones before and up to 4 years after HSCT (64). The reconstituted repertoire in CSF included a majority of new $\mathrm{T}$ cell clonotypes generated from hematopoietic stem cells (HSC) and a smaller population of clones generated from memory $\mathrm{T}$ cells in $\mathrm{PB}$ preexisting before the therapy and resistant to immune ablation (64). The persistence of those clones in patients with a sustained remission of inflammatory disease activity led to the conclusion that they are not self-reactive pathogenic mediators or are not able to induce disease activity in the new conditions.

An immunophenotyping study conducted by CyTOF mass cytometry and performed on cryopreserved PBMCs from patients with MS treated with HDIT/HSCT (HALT-MS) showed a redistribution of $\mathrm{T}$ cell subsets. The analysis showed an increased proportion of effector memory (CD45RA-CCR7-) and late effector (CD45RA+CCR7-) subtypes associated with reduction of naïve and $\mathrm{CM}$ at 2 months and a return of subsets at baseline levels at 1 and 2 years post-HSCT (65). The immune reconstitution was compared in patients that had long remission of disease to those that had relapses to define biomarkers associated with disease activity. The 5-year positive outcome from HSCT was related to higher absolute cell counts of memory and effector memory CD4 and CD8 T cells in PB at the baseline, and it was suggested as a biomarker (65). These results support that an immune resetting of the memory phenotype in the T cell compartment is relevant for the resolution of inflammation.

The immune reconstitution of $\mathrm{T}$ cells after non-myeloablative HSCT reported a decrement of total lymphocyte count up to the first year after treatment (66). CD4 T cells within the total T cell population remained reduced for the entire 2-year follow-up whereas non-significant differences were detected in the CD8 T cell pool (66). Significant changes in immunophenotyping were observed only in the CD8 compartment. Expansion of memory cells was reported at 6 months and 1-2 years posttreatment with decrement of naïve cells at the same time points (66).

\section{Myelin Antigen-Specific T Cells}

CD4 and CD8 $\mathrm{T}$ cell response (proliferation and cytokine production) to multiple myelin epitopes including whole myelin basic protein (MBP), myelin oligodendrocyte glycoprotein (MOG), and peptide pools derived from MBP and myelin proteolipid protein (PLP) remerged in the $\mathrm{PB}$ after high-intensity HSCT despite the ablation of T cell response to the memory antigen tetanus toxoid (TT) (67). Furthermore, the reconstituted $\mathrm{MBP}$-reactive $\mathrm{T}$ cells 12 months post-HSCT showed the same cytokine profiles compared to MBP-reactive $\mathrm{T}$ cells at baseline, with a greater capacity to secrete proinflammatory Th1 than Th2 cytokines (67).

\section{Effector Memory}

Mucosal-associated invariant T (MAIT) cells constitute a subset of unconventional $\mathrm{T}$ cells at the junction of innate and adaptive immune systems $(68,69)$. Human MAIT cells, 2 innate-like lymphocytes, express the semi-invariant TCR (TCR: iVa7.2Ja33) and are selected by the Major histocompatibility complex (MHC)-related protein 1, MR1 on hematopoietic cells (70). In the adult, MAIT cells represent $10 \%$ of mature $\mathrm{CD} 8^{+}$or $\mathrm{CD}^{-} \mathrm{CD} 8$ (DN) $\mathrm{T}$ cells. This population plays an important role against bacterial, yeast, and viral infections $(69,71)$ recognizing antigens (Ags) released from microbial riboflavin (vitamin B2) synthesis (72). In human, MAIT cells were defined as CD161 ${ }^{\text {hi }}$ IL$18 \mathrm{Ra}^{+} \mathrm{V} \alpha 7.2^{+} \gamma \delta^{-} \mathrm{CD}^{+}$lymphocytes with effector memory phenotype CD45RA ${ }^{-} \mathrm{CD} 45 \mathrm{RO}^{+} \mathrm{CD} 6 \mathrm{~L}^{\mathrm{lo}} \mathrm{CD} 122^{\mathrm{dim}} \mathrm{CD} 127^{\mathrm{hi}}$ $\mathrm{CD}^{\mathrm{h}}{ }^{\mathrm{hi}}(73)$, expression of the innate transcription factor promyelocytic leukemia zinc finger (PLZF), RAR-related orphan receptor gamma (ROR $\gamma \mathrm{t})$, and intermediate levels of T-Box transcription factor TBX21 (T-bet) (74). This subset of lymphocytes expresses heterogeneous levels of NK receptors and chemokines (CCR6, CXCR6, CXCR4, and CCR9) that consent the migration to peripheral tissue especially intestine and liver (73). MAIT cells secrete high levels of granzyme B, TNF $\alpha$, and IFN $\gamma$ upon CD3 and CD28 stimulation and high levels of IL-17 after PMA-ionomycin stimulation (73). MR1-Ag-loaded tetramers have been used for the specific identification of subsets of 
MAITs (75). MAIT cells were detected in white matter and perivascular infiltrates of postmortem MS brain tissues and were radically depleted after non-myeloablative HSCT and remained nearly undetectable in the $\mathrm{PB}$ for the whole follow-up period of 2 years (66). MAIT cells are defined as the major producer of IL-17 in the CD8 compartment, and their ablation after HSCT implicated the attenuation of Th17 and Th1-Th17 cells (67). In addition, pro-inflammatory MAIT cells were depleted in patients with MS at 3, 6, and 12 months post-HSCT (38). Flow cytometry analysis of $\mathrm{PB}$ mononuclear cells (PBMC) isolated in pre- and post-HSCT and stimulated under Th17-polarizing conditions for 6 days demonstrated a lower frequency of Th17 (IFN $\gamma^{-} \mathrm{IL}^{-17^{+}}$) and Th1-17 (IFN $\gamma^{+}$IL-17 ${ }^{+}$) after immune reconstitution (67). Similar results were observed in CD8 $\mathrm{T}$ cell responses. IL-17-producing $\mathrm{CD} 8 \mathrm{~T}(\mathrm{Tc} 17)$ responses (IFN $\gamma \mathrm{IL}^{+} 7^{+} \mathrm{CD} 8^{+} \mathrm{T}$ cells) were lower than the baseline, whereas no difference was reported for type 1 CD8 $\mathrm{T}$ cell ( $\mathrm{Tc1}$ ) responses (IFN $\gamma^{+} \mathrm{IL} 17^{-} \mathrm{CD}^{+} \mathrm{T}$ cells) (67). Accordingly, reduced levels of RoR $\gamma$-T (Th17 transcriptional factor) and an unchanged expression of T-bet (Th1 transcriptional factor) were detected in activated peripheral blood mononuclear cells (PBMC) in post-HSCT compared to the baseline (67). Those results were also confirmed by analysis of culture supernatants by ELISA. Lower levels of secretion of IL-17A were reported after-HSCT and associated with reduced levels of Th17-polarizing cytokines IL- $1 \beta$ and IL- 6 and unchanged levels of TGF $\beta$ and IL-23 (67).

Decrement of Th1-17 $\mathrm{T}$ cells was confirmed in a further investigation (65). Examination of $\mathrm{T}$ helper cells by chemokine expression on CD4 memory $\mathrm{T}$ cells (65) showed that CXCR ${ }^{+}{ }^{+}$CCR6 6 Th1 effector memory cells increased at 6 months and began to decrease at 2 years without reaching the baseline values. Contrary to $\mathrm{CXCR}^{-} \mathrm{CCR}^{+}{ }^{+} \mathrm{Th} 17$ effector memory cells that maintained the same levels during the follow-up, $\mathrm{CXCR}^{+} \mathrm{CCR}^{+}$Th1-17 effector memory cells lowered to the baseline at month 6 and year 2. Polyfunctional (co-expressing TNF $\alpha$ and IL-2) IFN $\gamma$ low- and high-producing CD8 T cells were examined over time. IFN $\gamma$ low-producing cells increased at month 2 and returned to the baseline at years 1 and 2 compared to IFN $\gamma$ high-producing CD8 T cells that remained the same at all the time points examined. Expression of programmed cell death protein-1 (PD-1) was observed to increase on CD4 and CD8 T cell populations at month 2 and to return to baseline levels at 1 and 2 years. The IFN $\gamma$ low- and high-producing CD8 T cells showed a remarkable increased coexpression of activation markers CD57, CD38, and HLA-DR at month 2 which returned to baseline levels at years 1 and 2 (65).

\section{Regulatory T Cells}

Regulatory CD4 $\mathrm{T}$ cells including $\mathrm{CD} 39^{+}$-expressing cells $\left(\mathrm{CD} 4^{+} \mathrm{CD} 25^{\mathrm{hi}} \mathrm{CD} 127^{-} \mathrm{CD} 39^{+}\right)(38)$ and Foxp $3^{+}$ $\left(\mathrm{CD} 4^{+} \mathrm{CD} 25^{\mathrm{hi}} \mathrm{CD} 127^{-} \mathrm{Foxp}^{+}\right)(66)$ and $\mathrm{CD} 8^{+} \mathrm{CD} 57^{+} \mathrm{T}$ cells increased after HSCT and non-myeloablative treatment (62, 65-67, 76). Memory CD4 $\mathrm{T}$ regs $\left(\mathrm{CD} 25^{+} \mathrm{CD} 127^{\text {low/- }} \mathrm{CD} 45 \mathrm{RA}^{-}\right)$ increased significantly at month 6 to return to baseline levels at 2 years post-HDIT/HSCT (65). $\mathrm{CD}^{+} \mathrm{CD}^{+} 7^{+} \mathrm{T}$ cells constituted a great proportion of the CD8 $\mathrm{T}$ cell pool after HSCT with immunoregulatory function related to the ability to suppress
CD4 $\mathrm{T}$ cell proliferation in cell coculture (66). Increases of cytotoxic T-lymphocyte antigen 4 (CTLA-4) on CD4 regulatory $\mathrm{T}$ cells and programmed cell death protein 1 (PD-1) on $\mathrm{CD} 19$ and $\mathrm{CD} 8{ }^{+} \mathrm{CD} 57^{+}$cells were associated with positive outcomes post-HSCT. PD-1 signaling and regulatory T cells were described as biological mechanisms restoring immune tolerance post-HSCT in HALT-MS (76).

\section{B Cells}

Total B cells reduced modestly at 2 months and increased from the baseline level at 1 and 2 years post-HDIT/HSCT (65). Naive $\mathrm{B}$ cells constituted the predominant subset within the circulating B cells at 1 and 2 years post-transplantation. An immunophenotyping study by flow cytometry was conducted on PBMCs isolated from 28 patients enrolled for AHSCT with HDIT/HSCT before and after therapy in a follow-up of 72 months (76). CD19 ${ }^{+} \mathrm{B}$ cell counts increased at 18 and 24 months post-HSCT, mainly in patients responsive to HSCT (76). Most of them are naïve cells and expressed PD-1 $(65,76)$.

\section{Oligoclonal IgG Bands}

(OCBs) in the CSF are a biomarker of intrathecal B and plasma cell activation in patients with MS. In one study, CSF analysis of 4 patients pre and after HSCT revealed that OCBs reduced in the CSF at a rate consistent with reduced ongoing IgG synthesis rates (77). Other studies that reported OCBs remained largely unchanged (30, $34,35,78)$. Persistence but reduction of OCBs in the CSF was observed at 2 years of the 4 -year patient follow-up with a reduction of CSF IgG levels (41). Long-term studies showed that OCB are decreased or disappeared. After HSCT, the IgG and IgM indices decreased and OCB were lower (79). A Swedish study with a 10year follow-up after HSCT demonstrated that $60 \%$ of patients lost CSF OCB and only one patient (10\%) had IgG above the normal levels and had relapse (80).

\section{Innate Immunity NK Cells}

The immune reconstitution of natural killer (NK) cells in the PB of patients with MS after receiving HSCT was investigated in 3 studies as reported $(38,66,81)$. In all the studies, CD56 NK cells expanded by month 2 . The frequencies of immunoregulatory CD $56^{\text {hi }} \mathrm{NK}$ cells (CD3 ${ }^{-} \mathrm{CD} 16^{-} \mathrm{CD} 56^{\text {hi }}$ ) increased significantly by 3 months and remained high in a follow-up of 12 months postHSCT (38). NK cells increased at 2 months and began returning to the baseline level by month 3 after HSCT (81). Frequencies of both the $\mathrm{CD} 56^{\mathrm{dim}}$ and $\mathrm{CD} 56^{\text {bright }} \mathrm{NK}$ cell subsets rose between month 3 and month 6 post-HSCT and remained elevated until month 18 and significantly higher at $12-18$ months post-HSCT (81). The ratio NK bright cells (CD56 $6^{\text {bright }} /$ CD56 ${ }^{\text {dim }}$ ) was 0.1 at the baseline, 0.6 from months 3 and 6 , and dropped to baseline levels by 24 months. The rapid immune reconstitution of NK cells was associated with incomplete ablation or presence of NK cells in the graft. Patients with a greater increase in NK cells showed the greatest reductions in Th17 responses associated with NK-mediated immune suppression (81).

Studies of immune reconstitution after myelo and nonmyeloablative HSCT have reported 1) decrement of 
TABLE 2 | Phenotype of human B, T, and natural killer (NK) cell subsets in the periphery.

\begin{tabular}{|c|c|c|c|c|}
\hline $\begin{array}{l}\text { Lymphocyte } \\
\text { subpopulations }\end{array}$ & Phenotype & Perturbation in MS & $\begin{array}{c}\text { Month } 6 \\
\text { post- } \\
\text { HSCT }\end{array}$ & $\begin{array}{l}\text { Year } 1 \\
\text { post- } \\
\text { HSCT }\end{array}$ \\
\hline
\end{tabular}

\section{T cell subsets $\left(\mathrm{CD}^{+}\right)$}

CD4-naïv $T$ cells

$\mathrm{CD} 4+$ central memory $\left(\mathrm{CD} 4^{+} \mathrm{T}_{\mathrm{CM}}\right)$

Th1 central memory ( $(\mathrm{Th} 1 \mathrm{CM})$

Th17 central memory $\left(T_{h} 17_{\mathrm{CM}}\right)$

Th1Th17 central memory (Th1Th17 $\mathrm{CM})$

$\mathrm{CD} 4+$ effector memory $\mathrm{T}$ cell $\left(\mathrm{CD} 4^{+} \mathrm{T}_{\mathrm{EM}}\right)$

Th1 effector memory (Th1 EM )

Th17 effector memory (Th17 $\mathrm{EM}$ )

Th1Th17 effector memory (Th1Th17 $\mathrm{EM}$ )

Terminal differentiated effector memory

CD4+ $T$ cell $\left(T_{\text {EMRA }}\right)$

Regulatory $\mathrm{CD} 4^{+} \mathrm{T}$ cells

$\mathrm{CD}^{+-}$naïv $\mathrm{T}$ cell

$\mathrm{CD}^{+}$central memory $\mathrm{T}$ cell $\left(\mathrm{CD} 8^{+} \mathrm{T}_{\mathrm{CM}}\right)$

$\mathrm{CD}^{+}$effector memory $\mathrm{T}$ cell $\left(\mathrm{CD} 8^{+} \mathrm{T}_{\mathrm{EM}}\right)$

Cytolytic CD8+ effector T cells (Tc1)

secrete IFN- $\gamma$

Cytolytic CD8 ${ }^{+}$effector T cells (Tc17)

secrete IL-17

Cytolytic CD8 ${ }^{+} T$ cells $(T c 17-1)$ secrete

IFN $\gamma$ and IL-17

MAIT cells

Terminal-differentiated effector memory

$\mathrm{CD}^{+} \mathrm{T}$ cell $\left(\mathrm{T}_{\text {EMRA }}\right)$

\section{B-cell subsets}

Transitional B cells

Naïve B cell subsets

Naïve B10 cell subsets

\begin{tabular}{|c|c|}
\hline & $\mathrm{CD} 19^{+} \mathrm{CD} 24^{\mathrm{hi}} \mathrm{CD} 27^{+}$ \\
\hline & $\mathrm{CD} 19^{+} \mathrm{CD} 27^{+}$ \\
\hline & $\mathrm{CD} 19^{+} \mathrm{CD} 38^{\mathrm{hi}}$ \\
\hline \multirow[t]{6}{*}{ Switched memory B cells (Bmems) } & $\operatorname{lgD} \mathrm{CD}^{-} 7^{+}$ \\
\hline & $\mathrm{CD}_{19^{+}} \mathrm{CD} 20^{\mathrm{hi}} \mathrm{CD} 45 \mathrm{RB}^{-} \mathrm{CD} 27^{-} \mathrm{CD}^{-} 5^{-}$ \\
\hline & $\mathrm{CD} 21^{-\mathrm{CD}} 38^{-} \mathrm{CD} 73^{-} \mathrm{CD} 4^{\mathrm{lo}} \mathrm{lg} \mathrm{G}^{\mathrm{hi}} \mathrm{CD} 185^{-}$ \\
\hline & $\mathrm{CD}_{184}{ }^{-} \mathrm{PD}-1^{+} \mathrm{CD} 11 \mathrm{c}^{+} \mathrm{T}^{- \text {bet }^{+}}$ \\
\hline & $\mathrm{CD} 45 \mathrm{RB}^{+} \mathrm{CD} 27^{+} \mathrm{CD} 3^{+} \operatorname{lgG}^{+} / \mathrm{lgA}^{+}$ \\
\hline & 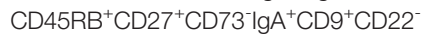 \\
\hline Long-lived Bmems & $\begin{array}{l}\mathrm{CD} 45 \mathrm{RB}^{-} \mathrm{CD} 27^{+/-} \operatorname{lgG}{ }^{+} / \mathrm{lgA}^{+} \mathrm{CD} 3^{+/-} \\
\mathrm{CD} 183^{+/-}\end{array}$ \\
\hline Effector Bmems & $\mathrm{CD}^{+} 5^{+} \operatorname{lgG}{ }^{+} / \operatorname{lgA}{ }^{+}$ \\
\hline Antibacterial specificity & $\mathrm{CD}^{-} 7^{-} \lg \mathrm{A}^{+}$ \\
\hline Aged or exhausted Bmems & $\mathrm{CD}^{-} 7^{-} \operatorname{lgG} 3^{+} / \operatorname{lgG}^{+}$ \\
\hline
\end{tabular}

Late memory B cells

Plasma cell subsets

Short-lived plasma cells

Long-lived plasma cells

Regulatory plasma cells

\section{NK subsets}

Regulatory NK cells

Cytotoxic NK cells

\section{$\mathrm{CD} 4{ }^{+} \mathrm{CCR} 7^{+} \mathrm{CD} 45 \mathrm{RA} \mathrm{A}^{+}$ \\ $\mathrm{CD} 4^{+} \mathrm{CCR} 7^{+} \mathrm{CD} 45 \mathrm{RA}$ \\ $\mathrm{CD}^{+}{ }^{+} \mathrm{CCR} 7{ }^{+} \mathrm{CD} 45 \mathrm{RA}^{-} \mathrm{CCR}^{-}{ }^{-} \mathrm{CXCR} 3^{+}$ \\ $\mathrm{CD}^{+}{ }^{+} \mathrm{CCR} 7^{+} \mathrm{CD}_{45 \mathrm{RA}}{ }^{-} \mathrm{CCR} 6^{+} \mathrm{CXCR} 3{ }^{-}$ \\ $\mathrm{CD}^{+}{ }^{+} \mathrm{CCR} 7{ }^{+}{ }^{\mathrm{CD}} 45 \mathrm{RA}^{-} \mathrm{CCR}^{+}{ }^{+} \mathrm{CXCR}^{+}{ }^{+}$ \\ $\mathrm{CD} 4^{+} \mathrm{CCR} 7^{-} \mathrm{CD} 45 \mathrm{RA}{ }^{-}$ \\ $\mathrm{CD}^{+}{ }^{+} \mathrm{CCR} 7^{-}{ }^{-} \mathrm{CD} 45 \mathrm{RAA}^{-} \mathrm{CCR}^{-} \mathrm{CXCR}^{+}{ }^{+}$ \\ $\mathrm{CD}^{+}{ }^{+} \mathrm{CCR} 7^{-} \mathrm{CD} 45 \mathrm{RA}^{-} \mathrm{CCR} 6^{+} \mathrm{CXCR}^{-}$ \\ $\mathrm{CD}^{+}{ }^{+} \mathrm{CCR} 7^{-} \mathrm{CD} 45 \mathrm{RA}^{-} \mathrm{CCR} 6^{+} \mathrm{CXCR} 3^{+}$ \\ $\mathrm{CD}^{+}{ }^{+} \mathrm{CCR} 7^{-} \mathrm{CD} 45 \mathrm{RA}^{+}$}

\section{$\mathrm{CD} 4^{+} \mathrm{CD} 25^{\mathrm{hi}} \mathrm{CD} 127-\mathrm{FOXP}^{+}$/ \\ $\mathrm{CD}^{+} \mathrm{CD} 25^{\mathrm{hi}} \mathrm{CD} 127^{-} \mathrm{CD} 39^{+}$ \\ $\mathrm{CD}^{+} \mathrm{CCR} 7^{+} \mathrm{CD} 45 \mathrm{RA}^{+}$ \\ $\mathrm{CD} 8^{+} \mathrm{CCR} 7^{+} \mathrm{CD} 45 \mathrm{RA}$ \\ $\mathrm{CD}^{+}{ }^{+} \mathrm{CCR} 7^{-} \mathrm{CD} 45 \mathrm{RA} \mathrm{A}^{-}$}

CD8 ${ }^{+}$CD $161^{\text {hiTCRVa7 }}{ }^{+} 2^{+} \mathrm{IL}-$ $18 \mathrm{R}^{+} \mathrm{CD} 45 \mathrm{RA} \mathrm{A}^{-} \mathrm{CD} 127^{\mathrm{hi}} \mathrm{CD} 95^{\mathrm{hi}}$ $\mathrm{CD}^{+}{ }^{+} \mathrm{CR} 7^{-} \mathrm{CD} 45 \mathrm{RA}^{+}$

$\lg \mathrm{D}^{\mathrm{lo} /} \operatorname{lgM}{ }^{+} \mathrm{CD} 10^{\mathrm{hi}} \mathrm{CD} 24^{\mathrm{hi}} \mathrm{CD} 38^{\mathrm{hi}}$ $\operatorname{lgD}+\mathrm{CD} 27+$ $\mathrm{CD} 45 \mathrm{RB}^{-} \mathrm{CD} 27^{-} \mathrm{CD}^{-} 8^{-\mathrm{CD}} 305^{+} \operatorname{lgD}{ }^{+} \mathrm{CD} 73^{-}$ $\mathrm{CD} 4 \mathrm{RBB}^{-\mathrm{CD}} 27^{-} \mathrm{CD} 38^{-} \operatorname{lgM}^{+} \mathrm{CD} 73^{+}$

$$
\begin{aligned}
& \mathrm{CD} 19^{+} \mathrm{CD} 24^{\mathrm{hi}} \mathrm{CD} 27^{+} \\
& \mathrm{CD} 19^{+} \mathrm{CD} 27^{+} \\
& \text {IgD-CD27 } 7^{+} \\
& \text {CD } 19^{+} \mathrm{CD} 2 \mathrm{O}^{\text {hi }} \mathrm{CD} 45 \mathrm{RB}^{-\mathrm{CD}} 27^{-\mathrm{CD}} 95 \\
& \text { CD21 }{ }^{-C D} 38^{-} \mathrm{CD}^{-} 3^{-} \mathrm{CD}^{\mathrm{l}} \mathrm{Ig} \mathrm{G}^{\mathrm{hi}} \mathrm{CD} 185 \\
& \text { 184 PD- } 1^{+} \mathrm{CD} 11 \mathrm{C}^{+} \mathrm{T} \text {-bet } \\
& \text { CD45RB }{ }^{+} \mathrm{CD} 27^{+}{ }^{\mathrm{CD}} 73^{-} \lg \mathrm{A}^{+} \mathrm{CD}{ }^{+} \mathrm{CD} 22 \\
& \mathrm{CD} 4 \mathrm{RB}^{-} \mathrm{CD} 27^{+/-} \operatorname{lgG}{ }^{+} / \mathrm{IgA}^{+} \mathrm{CD} 73^{+/-} \\
& \mathrm{CD} 183^{+/-} \\
& \mathrm{CD}^{-} 7^{-} \lg \mathrm{A}^{+} \\
& \mathrm{CD}^{\circ} 7^{-} \operatorname{lgG} 3^{+} / \operatorname{lgG} 2
\end{aligned}
$$

\section{$\lg \mathrm{D}^{-} \mathrm{CD} 27^{-}$}

$\mathrm{CD} 19^{+} \mathrm{CD} 38^{+} \mathrm{CD} 27^{\mathrm{hi}} \operatorname{lgG} / \operatorname{lgA}^{+} \operatorname{lgM}^{+}$
$\mathrm{CD} 19^{+} \mathrm{CD} 38^{+} \mathrm{CD} 27^{\text {hi }} \mathrm{CD} 184^{+} \operatorname{lgG} /$
$\lg \mathrm{I}^{+} \operatorname{lgM} \mathrm{M}^{+}$
$\mathrm{CD} 19^{+} \mathrm{CD} 138^{+}$

CD19+CD138 ${ }^{+}$

\section{$\mathrm{CD}^{-}{ }^{-C D} 56^{\text {hi }}$ \\ CD3-CD56 $6^{\text {dim }}$}

Detected in lesions, CSF

Detected in lesions, CSF

Detected in lesions, CSF

Detected in lesions, CSF

Detected in lesions, CSF

Detected in lesions, CSF

Detected in lesions, CSF

Detected in lesions, CSF

Detected in lesions, CSF

Detected in lesions, CSF

Detected in lesions, CSF

Detected in lesions, CSF

Detected in lesions, CSF

Detected in lesions, CSF

Detected in lesions, CSF

Detected in lesions, CSF

Detected in lesions, CSF

Dysfunctional

Abnormal

$\downarrow \downarrow$

$\uparrow \uparrow$

$b_{\downarrow} \cong$

$\begin{array}{ccc}{ }^{b} & \cong & \cong \\ \downarrow & \cong & \cong \\ \cong & \cong & \cong \\ \downarrow \downarrow & \downarrow \downarrow & \cong \\ \downarrow \downarrow & \downarrow \downarrow & \cong \\ \uparrow \uparrow & \cong & \cong \\ \cong & \cong & \cong \\ \downarrow \downarrow & \downarrow \downarrow & \downarrow \downarrow \\ \downarrow \downarrow & \downarrow \downarrow & \downarrow \downarrow \\ { }_{\uparrow} \uparrow & \stackrel{d}{d} & \cong\end{array}$

${ }^{c}$ Aarrow $\uparrow=$ increase, ${ }^{b}$ arrow $\downarrow=$ decrease, ${ }^{d} \approx=$ approximaly equal, ${ }^{e} ?=$ unknown.

Subsets of lymphocytes that are described as "pathogenic" in MS and kinetics of immune reconstitution post-HSCT compared to the baseline (pre-treatment) in MS.
-Antigen presenting cells capacity (self-antigens)? promoting autoreactive cell responses,

-Increased release of GM-CSF,IL-6,TNF $\alpha$ and lymphotoxin- $\alpha$ upon BCR and CD40 engagement,

-Bmems present RASPGRP2-derived epitopes that are targeted on Neuron by CD4 T cells, -Increased of Bmems in the CNS that contribute to generation of ectopic lymphoid structures (ELS).

-Contribute to large amount of high-affinity antibodies, high levels of immunoglobulin IgG and IgM in the cerebrospinal liquid,

Dysregulated or impaired Dysregulated or impaired

$\begin{array}{ccc}\uparrow \uparrow \uparrow & \uparrow \uparrow & \cong \\ \downarrow & \cong & \cong \\ \downarrow & \cong & \cong \\ \uparrow \uparrow & \cong & \cong \\ \cong & \cong & \cong \\ \downarrow & \downarrow & \downarrow \\ \downarrow & \downarrow & \downarrow \\ \downarrow \downarrow \downarrow \downarrow & \downarrow \downarrow \downarrow \downarrow & \downarrow \downarrow \downarrow \downarrow\end{array}$

$\begin{array}{ccc}{ }^{e} ? & ? & ? \\ \downarrow & \uparrow \uparrow & \uparrow \uparrow\end{array}$

? ? ?

\section{$\downarrow \quad \downarrow \quad \downarrow$}


inflammatory subsets Th17 and Th17-1;2) increment of regulatory populations represented by regulatory CD4 $\mathrm{T}$ cells, $\mathrm{CD} 8{ }^{+} \mathrm{CD} 57^{+} \mathrm{T}$ cells, and CD56 ${ }^{\text {hi }} \mathrm{NK}$ cells; 3 ) renewal of the TCR repertoire in $\mathrm{CD} 4 \mathrm{~T}$ cells associated with thymic output; and 4) resetting of the $\mathrm{B}$ cell compartment with an enrichment of naïve B cells. The kinetics of immune reconstitution after HSCT were reported as shown in Table 2 while the relevant biological processes in the immune reconstitution in patients with MS post-HSCT are recapitulated as shown in Figure 1.

\section{New Questions and Perspective on Future Studies \\ Stem Memory Cells}

Self-reactive memory B and T cells have a crucial role in the pathogenesis of MS as reported in clinical-pathological and functional studies (82-86). The knowledge of molecular mechanisms that regulate or produce immunological memory could be essential for the development of immune therapeutic intervention in MS. Long-lived memory cells are generated from adaptive immunity and guarantee a longlasting protection against microbes and tumors. However, immunological memory can favor chronic inflammation and contribute to the development and maintenance of immunemediated diseases. Among memory $\mathrm{T}$ cell subsets, stem memory $\mathrm{T}$ cells (Tscm) have the capacity of self-renewal and multipotency. Tscm differentiate in vitro from naïve $\mathrm{T}$ cells by triggering Wnt-b-catenin signaling during $\mathrm{T}$ cell priming (87, 88). Tscm constitute a small proportion of circulating CD4 and CD8 T cells (>2\%-3\%) with naïve-like phenotypes (CD45RA ${ }^{+}$, $\mathrm{CCR}^{+}, \mathrm{CD} 2 \mathrm{~L}^{+}, \mathrm{CD} 27^{+}, \mathrm{CD} 28^{+}$, and IL-7R $\left.\alpha^{+}\right)$and memory markers $\left(\mathrm{CD} 5^{+}, \mathrm{CXCR}^{+}, \mathrm{IL}-2 \mathrm{R} \beta^{+}, \mathrm{CD} 58^{+}\right.$, and $\left.\mathrm{CD} 11 \mathrm{a}^{+}\right)$. Tscm showed either memory and naïve $\mathrm{T}$ cell properties, including a low level of TCR rearrangement excision circles (TREC), ability to acquire rapidly effector function in response to antigens and differentiation in memory subtypes, dependence on IL-15 and IL-7 for homeostatic turnover, asymmetric proliferation typical of multipotent cells, homing to lymph node and tumor, and viral antigen specificities (89). Compared to naïve $\mathrm{T}$ cells, Tscm are maintained by extensive proliferation and display a higher level of telomerase activity that gives them the HSC features (90). Moreover, Tscm lymphocytes can differentiate directly from naive precursors infused within the graft (91), and the extent of Tscm generation correlates with IL-7 serum levels. In agreement with recent findings, Tscm could constitute the precursors and the reservoir of autoreactive clones causing autoimmune disorders. Th17 cells, described as pathogenic in chronic autoimmunity (92), have been highlighted to persist longer and expand more efficiently than Th1-derived cells in vivo endowed of the molecular program of survival and selfrenewal. Long-term CD8 T cell responses to yellow virus are detectable over 25 years after vaccination and show a naïve-like

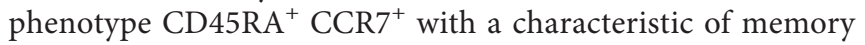
cells $(93,94)$. Therefore, the relevance of $\mathrm{Tscm}$ in the differentiation of long-term memory $\mathrm{T}$ cells was obtained monitoring over several years $\mathrm{T}$ lymphocytes, genetically modified to express thymidine kinase (TK) suicide gene (95, 96). Tscm have been investigated in immune-mediated disorders. In type I diabetes (TID), beta-cell-specific $\mathrm{T}$ cells persist for long periods generating an antigenic response to pancreatic islet transplant recipients. The mechanisms that preserve effector and memory features in beta-cell-specific CD8 T cells through the life of type I diabetic patients have been investigated (97). Single cell ATAQ-seq showed the coexistence of naïve and effector-associated epigenetic programs in tetramer positive beta-cell-specific CD8 T cells isolated from patients with type I diabetes (97). This hybrid condition supports the hypothesis that a long-lived population of cells that retain effector potential may preserve a sustained self-reactive state. Moreover, beta cell-specific CD8 T cells isolated and stimulated for 14 days maintain multipotencyassociated epigenetic programming after undergoing extensive antigen-dependent proliferation (97). CD161 ${ }^{\text {hi }} \mathrm{CD}^{+} \mathrm{Tscm}$ cells have antiviral specificities and regenerate the antiviral memory pool after chemotherapy displaying futures of memory stem cells $(98,99) . \mathrm{CD}^{+}$Tscm cells in systemic lupus erythematosus (SLE) patients showed a gene profile facilitating $\mathrm{T}$ follicular helper ( $\mathrm{Tfh}$ ) cell differentiation and antibody production (100). Tfh has been described dysfunctional in SLE and to help B cells in the generation of germinal centers and production of high-affinity and isotypeswitched antibodies (101). Moreover, levels of CD4 Tscm increase and correlate with disease activity in patients with rheumatoid arthritis (RA). Receiving a pro-survival signaling from TNFR2, CD4 Tscm cells undergo oligoclonal TCR repertoire expansion that constitutes a reservoir of autoreactive cells (102). The ability of Tscm to differentiate in Tfh and participate to high-affinity and isotype-switched antibodies confers to this $\mathrm{T}$ cell subset a potential pathogenic role in MS. Differentiation and self-renewal of memory stem cells in the healthy immune system and in autoimmune diseases are illustrated in Figure 2. The contribution of B cells to the pathogenesis of MS has been recently reviewed in depth and has highlighted the need for further investigation of B immune reconstitution (85).

\section{Secondary Autoimmunity}

Development of a new (secondary) autoimmune disease in patients with a preexisting (primary) autoimmune condition has been reported after treatment with autologous HSCT at rates ranging from $2 \%$ to $14 \%$ (103). The rates of secondary autoimmune diseases, termed henceforth 2ndADs, following treatment with ALEM are higher, requiring special monitoring in patients with MS and cautioning against the use of ALEM as lymphodepleting treatment in HSCT regimes. The occurrence, risk factors, and immunological mechanisms of 2 ndADs after treatment with HSCT have been the specific focus of a recent publication in which the authors suggest that an imbalance of effector and regulatory $\mathrm{T}$ and $\mathrm{B}$ cells, or delayed reconstitution of the latter, may underlie the occurrence of the adverse event (103). This notion further supports the rationale of studies of immune reconstitution 


\section{Immune reconstitution in MS post-HSCT}

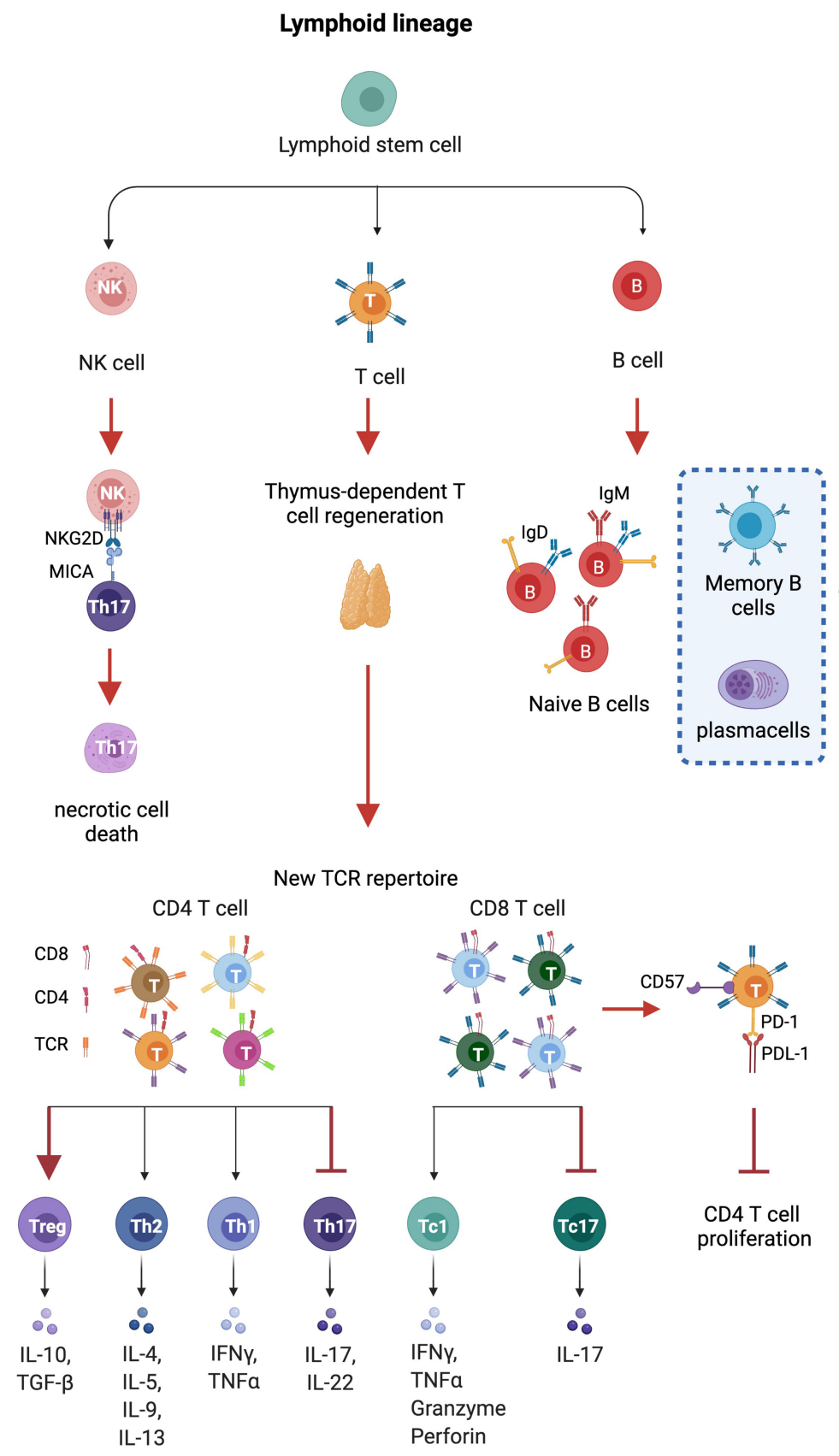

FIGURE 1 | Immune reconstitution in MS after HSCT. Thymus-dependent T cell regeneration and immune regulation mediated by T and natural killer (NK) cells constitute the major identified pathways influencing immune reconstitution in patients with MS after HSCT. Thymus-derived CD4 T cells show a new, diverse repertoire and deletion of preexisting CD4 clones. CD8 T cells show an incomplete renewal of TCR repertoire suggesting expansion of residual or regenerated virusspecific clones. Increase of regulatory $\mathrm{CD}^{+} \mathrm{FOXP3}^{+}, \mathrm{CD} 8^{+} \mathrm{CD} 57^{+} \mathrm{T}$ cells, and NK cells and eradication of pro-inflammatory Th17 and Th17-1 cells (MAIT) are observed after HSCT. NK cells induce necrotic cell death in Th17 and Th17-1 cells by the NKG2D pathway, while CD8 ${ }^{+} \mathrm{CD} 57^{+}$cells suppress CD4 ${ }^{+}$T cell proliferation. Anergy is reported on $\mathrm{CD} 8^{+} \mathrm{T}$ cells that express high levels of CD57, a marker of senescence, and inhibitory effects are exerted by the immune checkpoint inhibitor PD-1. HSC, hematopoietic stem cells; CLP, common lymphocyte progenitor; NK regs, regulatory natural killer CD3-CD56 hi. Figure created with BioRender.com. 


\section{Memory stem cells in healthy and autoimmune diseases}

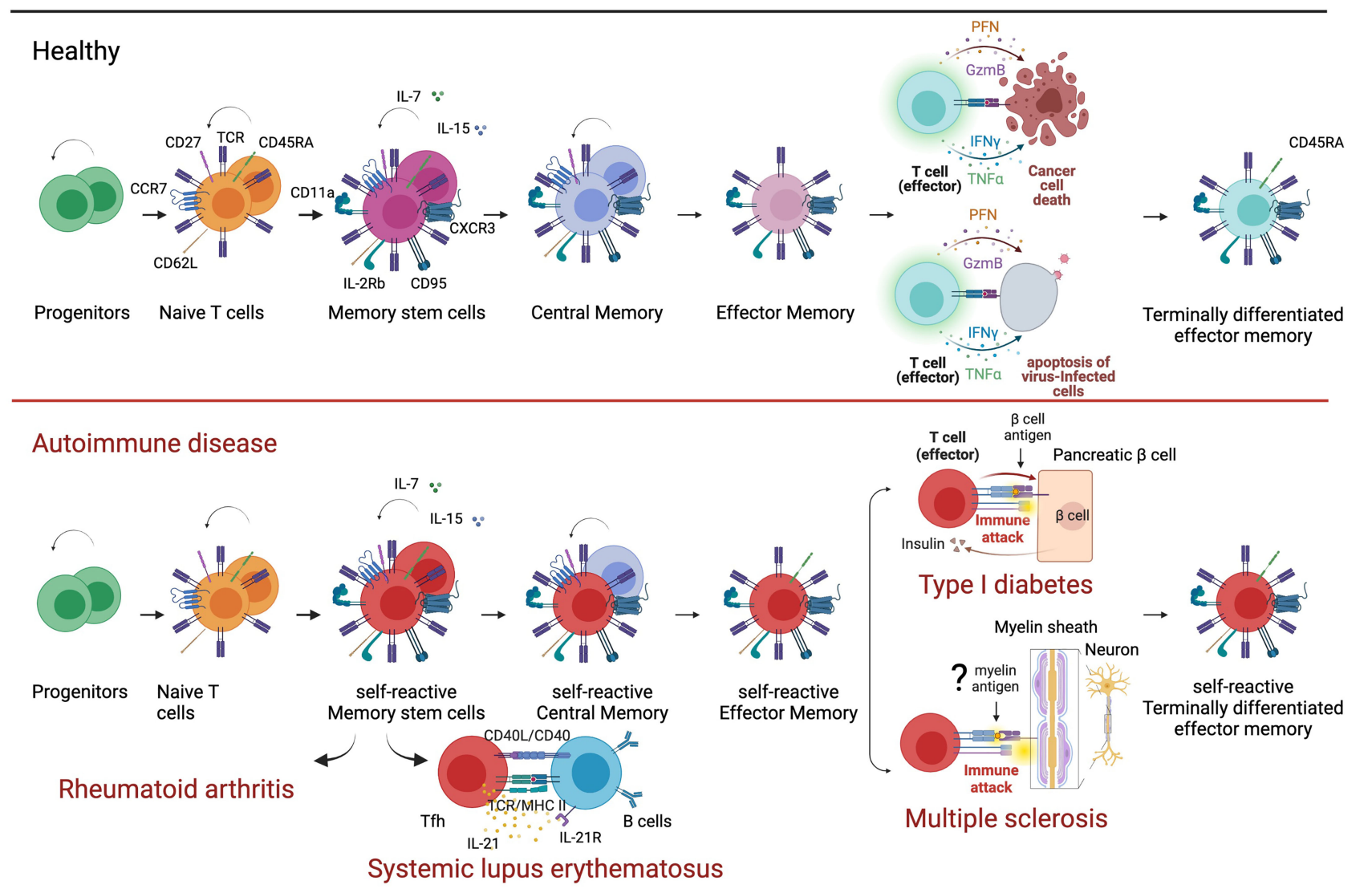

FIGURE 2 | Stem memory cells in healthy and autoimmune disease. Stem memory cells constitute a subset of T cells with self-renewal and multipotent capacity. Generated from naïve cells, stem memory cells develop into memory subsets including central memory and effector memory. Stem memory cells express a naïve-like

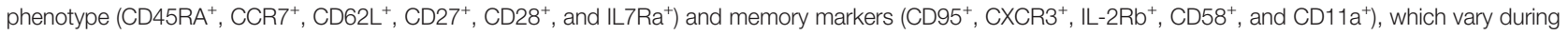
further differentiation. While essential to immunological memory in healthy immune system, memory stem cells also represent a reservoir of autoreactive clones in autoimmune disease. For example, in type I diabetes (TDI) self-reactive $\beta$-cell-specific CD8 T cells maintain a memory stem cell phenotype that favors a persistent production of pathogenic clones. In systemic lupus erythematosus, memory stem cells differentiate easily into T follicular helper cells (Tfh) that contribute to B cell differentiation and antibody production. In multiple sclerosis, stem memory cells recognizing, hypothetically, myelin antigens could represent a supply of proinflammatory and cytotoxic cells targeting myelin and damaging neurons. Figure created with BioRender.com.

after HSCT, particularly including the kinetics of reconstitution of regulatory and effector cells and examining the correlation with any 2 ndADs.

\section{Vaccination Following HSCT}

HSCT recipients often lose immunity to vaccine-preventable diseases following transplantation and are therefore considered "never vaccinated" $(104,105)$. In patients who have received an autologous HSCT, pathogen-specific immune reconstitution in the absence of vaccination can be poor even several years posttransplant, with $98.2 \%, 100 \%$, and $34.5 \%$ showing titers below protective thresholds for against diphtheria, Streptococcus pneumoniae, and measles virus, respectively (106). International and EBMT guidelines therefore recommend commencement of a routine vaccination program at 3-6 months after HSCT $(6,107)$. Vaccine responses can, however, be suboptimal in the first year post-HSCT, with minimal immunogenicity to influenza vaccines seen during the first 6 months (108). Similarly, emerging data suggest that responses to SARS-CoV-2 mRNA vaccines are lower during the first 12 months post-HSCT (109). However, preliminary reports in HSCT recipients suggest around $60 \%$ positivity (110) rate for SARS-CoV-2 antibodies post-vaccination, and the presence of a memory $\mathrm{T}$ cell response (111) elicited by a second dose of vaccine.

Post-HSCT vaccination offers opportunity to explore whether beneficial pathogen-specific immunity can be induced while maintaining the broad post-transplant immune tolerance associated with favorable outcomes in MS. It is possible that the degree of tolerance present may be associated with the magnitude of response to specific vaccines, especially during the first few months after transplant. Nevertheless, post-HSCT vaccine responses may be superior to those seen in patients who have received certain DMTs who have an ongoing 
immunosuppressive state. Although there is currently limited evidence for relapse of autoimmune conditions post-HSCT due to vaccination-induced disruption of immune tolerance, it is important to establish the safety of vaccine programs in patients with MS who have undergone HSCT, particularly with more novel vaccine technologies.

\section{Vaccination and DMT}

Immune response to vaccinations could be hampered by immune-suppressive treatments. Vaccine humoral immune responses were reduced in patients treated with NAT and significantly impaired by anti-CD20 monoclonal antibody therapies. The timing of vaccination played an important role in those treated with ALEM (112). The vaccine-induced longterm immunologic memory against pathogens relies both on humoral and on cellular immune responses. Despite patients treated with anti-CD20 antibodies showing significantly reduced humoral response to SARS-CoV-2 mRNA vaccination, as compared to untreated patients (113), they generated robust CD4 and CD8 T cell responses suggesting that vaccinating B celldeficient patients are still likely to provide some measure of immunity to SARS-CoV-2 (114).

\section{CONCLUSIONS}

Treatment with autologous HSCT for patients with aggressive RRMS has been demonstrated to be highly effective $(37,115)$ with a significant reduction of treatment related mortality over time (currently < 1\%). The American Society of Bone Marrow Transplantation (ASBMT) and the European Bone Marrow Transplantation (EBMT) Autoimmune Diseases Working Party (ADWP) have endorsed HSCT as a "standard of care" treatment for DMT-resistant poor-prognosis inflammatory MS $(7,116)$. Infection risk related to chronic or cyclic immune suppression from DMTs is initially low but accumulates over time with long term, while in HSCT the risk is early after transplantation with patients benefiting from a lack of longlasting immune suppression.

Results from studies of immune reconstitution post-HSCT showed a change in immune profile suggesting a shift toward tolerance, characterized by depletion of pro-inflammatory TH1/ 17 cells, senescence of terminally differentiated effector memory cells, increase of naïve cells with new TCR repertoire, and regulatory profile in early stage. Despite the knowledge of the $\mathrm{T}$ cell compartment, little information is available for $\mathrm{B}$ cell immune reconstitution.

Tscm cells represent an early stage of memory cells with propriety of self-renewal and effector cells. Their susceptibility to generate chronic inflammation and autoimmune disease has spotlighted the necessity to investigate this population in MS. Studies focused on defining the differentiation pathway, transcriptome profiles, and characterization of molecules associated with stem and effector-like function before and after HSCT could help to understand the mechanisms of action of the procedure and potentially elucidate the reason for the less common occurrences of disease persistence or reactivation, and 2ndADs.

\section{AUTHOR CONTRIBUTIONS}

MC and PM conceptualized the manuscript. MC wrote and revised the manuscript. AG and GB wrote the paragraphs: "Disease modifying treatments in MS", "HSCT versus DMT", and "Vaccination and DMT" and revised the manuscript. TdS wrote the paragraph "Vaccination following HSCTA" and revised the manuscript. TA, RG, JS, and BS critically reviewed the manuscript for important intellectual content and edited the manuscript. PM supervised, reviewed, and revised the manuscript. All authors contributed to the article and approved the submitted version.

\section{FUNDING}

This review was funded by the European Society for Blood and Marrow Transplantation Leiden Netherland Reference: ADWP.

\section{ACKNOWLEDGMENTS}

MC and PM have received support from the National Institute of Health Research (NIHR; EME Project: 16/126/26 to PM) and from the Elena Pecci research project and the Fondazione Careggi Onlus. The authors contribute this article on behalf of the Autoimmune Diseases Working Party (ADWP) of the European Society for Blood and Marrow Transplantation (EBMT). We acknowledge the ADWP, all EBMT member centers, and their clinicians, data managers, and patients for their essential contributions to the EBMT registry. The EBMT Autoimmune Diseases Working Party (ADWP) included: Raffaella Greco (Chair), Tobias Alexander (Secretary), John Snowden (Chair April 2016-May 2020), Manuela Badoglio (Study Coordinator), Myriam Labopin (Statistician), and actively participating clinicians; Mario Abinun, Shashikant Apte, Renate Arnold, Ariadna Domenech (EBMT Nurses Group representative), Charlotte Brierley, Joachim Burman, Cristina Castilla-Llorente, Nichola Cooper, Giulia Daghia, Thomas Daikeler, Nicoletta del Papa, Jeska de Vries- Bouwstra, Dominique Farge, Jurgen Finke, Hans Hagglund, Chris Hawkey, Jörg Henes, Falk Hiepe, Helen Jessop (EBMT Nurses Group representative), David Kiely, Majid Kazmi, Kirill Kirgizov, Ellen Kramer (also representing the EBMT Patient Advocacy Committee), Gianluigi Mancardi, Zora Marjanovic, Roland Martin, Thierry Martin, David Ma, John Moore, Paul Miller, Paolo Muraro, Maria-Carolina Oliveira, Alexey Polushin, Francesco Onida, Belinda Simoes, Mathieu Puyade, Igor Resnick, Elena Ricart, Montserrat Rovira, Riccardo Saccardi, Muhammad Saif, Ioanna Sakellari, Basil Sharrack, Emilian Snarski, Hans Ulrich Scherer, Claudia Sossa, Barbara Withers, Nico Wulffraat, Eleanora Zaccara. 


\section{REFERENCES}

1. Compston A, Coles A. Multiple Sclerosis. Lancet (2008) 372(9648):1502-17. doi: 10.1016/S0140-6736(08)61620-7

2. Dendrou CA, Fugger L, Friese MA. Immunopathology of Multiple Sclerosis. Nat Rev Immunol (2015) 15(9):545-58. doi: 10.1038/nri3871

3. Hauser SL. Multiple Lessons for Multiple Sclerosis. N Engl J Med (2008) 359 (17):1838-41. doi: 10.1056/NEJMe0806738

4. Jelcic I, Al Nimer F, Wang J, Lentsch V, Planas R, Jelcic I, et al. Memory B Cells Activate Brain-Homing, Autoreactive CD4(+) T Cells in Multiple Sclerosis. Cell (2018) 175(1):85-100.e23. doi: 10.1016/j.cell.2018.08.011

5. Simpson A, Mowry EM, Newsome SD. Early Aggressive Treatment Approaches for Multiple Sclerosis. Curr Treat Options Neurol (2021) 23 (7):19. doi: 10.1007/s11940-021-00677-1

6. Greco R, Alexander T, Burman J, Del Papa N, de Vries-Bouwstra J, Farge D, et al. Hematopoietic Stem Cell Transplantation for Autoimmune Diseases in the Time of COVID-19: EBMT Guidelines and Recommendations. Bone Marrow Transplant (2021) 56(7):1493-508. doi: 10.1038/s41409-02101326-6

7. Sharrack B, Saccardi R, Alexander T, Badoglio M, Burman J, Farge D, et al. Autologous Haematopoietic Stem Cell Transplantation and Other Cellular Therapy in Multiple Sclerosis and Immune-Mediated Neurological Diseases: Updated Guidelines and Recommendations From the EBMT Autoimmune Diseases Working Party (ADWP) and the Joint Accreditation Committee of EBMT and ISCT (JACIE). Bone Marrow Transplant (2020) 55(2):283-306. doi: 10.1038/s41409-019-0684-0

8. Miller DH, Khan OA, Sheremata WA, Blumhardt LD, Rice GP, Libonati MA, et al. A Controlled Trial of Natalizumab for Relapsing Multiple Sclerosis. N Engl J Med (2003) 348(1):15-23. doi: 10.1056/NEJMoa020696

9. Polman CH, O’Connor PW, Havrdova E, Hutchinson M, Kappos L, Miller $\mathrm{DH}$, et al. A Randomized, Placebo-Controlled Trial of Natalizumab for Relapsing Multiple Sclerosis. N Engl J Med (2006) 354(9):899-910. doi: 10.1056/NEJMoa044397

10. Prosperini L, Sacca F, Cordioli C, Cortese A, Buttari F, Pontecorvo S, et al. Real-World Effectiveness of Natalizumab and Fingolimod Compared With Self-Injectable Drugs in Non-Responders and in Treatment-Naive Patients With Multiple Sclerosis. J Neurol (2017) 264(2):284-94. doi: 10.1007/ s00415-016-8343-5

11. Butzkueven H, Kappos L, Pellegrini F, Trojano M, Wiendl H, Patel RN, et al. Efficacy and Safety of Natalizumab in Multiple Sclerosis: Interim Observational Programme Results. J Neurol Neurosurg Psychiatry (2014) 85(11):1190-7. doi: 10.1136/jnnp-2013-306936

12. Bloomgren G, Richman S, Hotermans C, Subramanyam M, Goelz S, Natarajan A, et al. Risk of Natalizumab-Associated Progressive Multifocal Leukoencephalopathy. N Engl J Med (2012) 366(20):1870-80. doi: 10.1056/ NEJMoa1107829

13. Ryerson LZ, Foley J, Chang I, Kister I, Cutter G, Metzger RR, et al. Risk of Natalizumab-Associated PML in Patients With MS is Reduced With Extended Interval Dosing. Neurology (2019) 93(15):e1452-62. doi: 10.1212/WNL.0000000000008243

14. West TW, Cree BA. Natalizumab Dosage Suspension: Are We Helping or Hurting? Ann Neurol (2010) 68(3):395-9. doi: 10.1002/ana.22163

15. Hauser SL, Waubant E, Arnold DL, Vollmer T, Antel J, Fox RJ, et al. B-Cell Depletion With Rituximab in Relapsing-Remitting Multiple Sclerosis. N Engl J Med (2008) 358(7):676-88. doi: 10.1056/NEJMoa 0706383

16. Hauser SL, Bar-Or A, Comi G, Giovannoni G, Hartung HP, Hemmer B, et al. Ocrelizumab Versus Interferon Beta-1a in Relapsing Multiple Sclerosis. N Engl J Med (2017) 376(3):221-34. doi: 10.1056/NEJMoa1601277

17. Faissner S, Gold R. Progressive Multiple Sclerosis: Latest Therapeutic Developments and Future Directions. Ther Adv Neurol Disord (2019) 12:1756286419878323. doi: 10.1177/1756286419878323

18. Pei SN, Chen CH, Lee CM, Wang MC, Ma MC, Hu TH, et al. Reactivation of Hepatitis B Virus Following Rituximab-Based Regimens: A Serious Complication in Both HBsAg-Positive and HBsAg-Negative Patients. Ann Hematol (2010) 89(3):255-62. doi: 10.1007/s00277-009-0806-7

19. Ciardi MR, Iannetta M, Zingaropoli MA, Salpini R, Aragri M, Annecca R, et al. Reactivation of Hepatitis B Virus With Immune-Escape Mutations
After Ocrelizumab Treatment for Multiple Sclerosis. Open Forum Infect Dis (2019) 6(1):ofy356. doi: 10.1093/ofid/ofy356

20. Simpson-Yap S, De Brouwer E, Kalincik T, Rijke N, Hillert JA, Walton C, et al. Associations of Disease-Modifying Therapies With COVID-19 Severity in Multiple Sclerosis. Neurology (2021) 97(19):e1870-85. doi: 10.1212/ WNL.0000000000012753

21. Cohen JA, Coles AJ, Arnold DL, Confavreux C, Fox EJ, Hartung HP, et al. Alemtuzumab Versus Interferon Beta 1a as First-Line Treatment for Patients With Relapsing-Remitting Multiple Sclerosis: A Randomised Controlled Phase 3 Trial. Lancet (2012) 380(9856):1819-28. doi: 10.1016/S0140-6736 (12)61769-3

22. Coles AJ, Twyman CL, Arnold DL, Cohen JA, Confavreux C, Fox EJ, et al. Alemtuzumab for Patients With Relapsing Multiple Sclerosis After DiseaseModifying Therapy: A Randomised Controlled Phase 3 Trial. Lancet (2012) 380(9856):1829-39. doi: 10.1016/S0140-6736(12)61768-1

23. Havrdova E, Arnold DL, Cohen JA, Hartung HP, Fox EJ, Giovannoni G, et al. Alemtuzumab CARE-MS I 5-Year Follow-Up: Durable Efficacy in the Absence of Continuous MS Therapy. Neurology (2017) 89(11):1107-16. doi: 10.1212/WNL.0000000000004313

24. Coles AJ, Cohen JA, Fox EJ, Giovannoni G, Hartung HP, Havrdova E, et al. Alemtuzumab CARE-MS II 5-Year Follow-Up: Efficacy and Safety Findings. Neurology (2017) 89(11):1117-26. doi: 10.1212/WNL. 0000000000004354

25. Baker D, Herrod SS, Alvarez-Gonzalez C, Giovannoni G, Schmierer K. Interpreting Lymphocyte Reconstitution Data From the Pivotal Phase 3 Trials of Alemtuzumab. JAMA Neurol (2017) 74(8):961-9. doi: 10.1001/ jamaneurol.2017.0676

26. Giovannoni G, Soelberg Sorensen P, Cook S, Rammohan K, Rieckmann P, Comi G, et al. Safety and Efficacy of Cladribine Tablets in Patients With Relapsing-Remitting Multiple Sclerosis: Results From the Randomized Extension Trial of the CLARITY Study. Mult Scler (2018) 24(12):1594604. doi: $10.1177 / 1352458517727603$

27. Signori A, Sacca F, Lanzillo R, Maniscalco GT, Signoriello E, Repice AM, et al. Cladribine vs Other Drugs in MS: Merging Randomized Trial With Real-Life Data. Neurol Neuroimmunol Neuroinflamm (2020) 7(6):e878. doi: 10.1212/NXI.0000000000000878

28. Fassas A, Anagnostopoulos A, Kazis A, Kapinas K, Sakellari I, Kimiskidis V, et al. Peripheral Blood Stem Cell Transplantation in the Treatment of Progressive Multiple Sclerosis: First Results of a Pilot Study. Bone Marrow Transplant (1997) 20(8):631-8. doi: 10.1038/sj.bmt.1700944

29. Burt RK, Traynor AE, Cohen B, Karlin KH, Davis FA, Stefoski D, et al. T Cell-Depleted Autologous Hematopoietic Stem Cell Transplantation for Multiple Sclerosis: Report on the First Three Patients. Bone Marrow Transplant (1998) 21(6):537-41. doi: 10.1038/sj.bmt.1701129

30. Openshaw H, Lund BT, Kashyap A, Atkinson R, Sniecinski I, Weiner LP, et al. Peripheral Blood Stem Cell Transplantation in Multiple Sclerosis With Busulfan and Cyclophosphamide Conditioning: Report of Toxicity and Immunological Monitoring. Biol Blood Marrow Transplant (2000) 6 (5A):563-75. doi: 10.1016/S1083-8791(00)70066-8

31. Mancardi GL, Saccardi R, Filippi M, Gualandi F, Murialdo A, Inglese M, et al. Autologous Hematopoietic Stem Cell Transplantation Suppresses GdEnhanced MRI Activity in MS. Neurology (2001) 57(1):62-8. doi: 10.1212/ WNL.57.1.62

32. Nash RA, Bowen JD, McSweeney PA, Pavletic SZ, Maravilla KR, Park MS, et al. High-Dose Immunosuppressive Therapy and Autologous Peripheral Blood Stem Cell Transplantation for Severe Multiple Sclerosis. Blood (2003) 102(7):2364-72. doi: 10.1182/blood-2002-12-3908

33. Kozak T, Havrdova E, Pit'ha J, Gregora E, Pytlik R, Maaloufova J, et al. HighDose Immunosuppressive Therapy With PBPC Support in the Treatment of Poor Risk Multiple Sclerosis. Bone Marrow Transplant (2000) 25(5):525-31. doi: 10.1038/sj.bmt.1702180

34. Capello E, Saccardi R, Murialdo A, Gualandi F, Pagliai F, Bacigalupo A, et al. Intense Immunosuppression Followed by Autologous Stem Cell Transplantation in Severe Multiple Sclerosis. Neurol Sci (2005) 26 Suppl 4: S200-3. doi: 10.1007/s10072-005-0514-6

35. Bowen JD, Kraft GH, Wundes A, Guan Q, Maravilla KR, Gooley TA, et al. Autologous Hematopoietic Cell Transplantation Following High-Dose Immunosuppressive Therapy for Advanced Multiple Sclerosis: Long-Term 
Results. Bone Marrow Transplant (2012) 47(7):946-51. doi: 10.1038/ bmt.2011.208

36. Fassas A, Kimiskidis VK, Sakellari I, Kapinas K, Anagnostopoulos A, Tsimourtou V, et al. Long-Term Results of Stem Cell Transplantation for MS: A Single-Center Experience. Neurology (2011) 76(12):1066-70. doi: 10.1212/WNL.0b013e318211c537

37. Muraro PA, Pasquini M, Atkins HL, Bowen JD, Farge D, Fassas A, et al. Long-Term Outcomes After Autologous Hematopoietic Stem Cell Transplantation for Multiple Sclerosis. JAMA Neurol (2017) 74(4):459-69. doi: 10.1001/jamaneurol.2016.5867

38. Moore JJ, Massey JC, Ford CD, Khoo ML, Zaunders JJ, Hendrawan K, et al. Prospective Phase II Clinical Trial of Autologous Haematopoietic Stem Cell Transplant for Treatment Refractory Multiple Sclerosis. J Neurol Neurosurg Psychiatry (2019) 90(5):514-21. doi: 10.1136/jnnp-2018-319446

39. Fagius J, Lundgren J, Oberg G. Early Highly Aggressive MS Successfully Treated by Hematopoietic Stem Cell Transplantation. Mult Scler (2009) 15 (2):229-37. doi: 10.1177/1352458508096875

40. Burman J, Iacobaeus E, Svenningsson A, Lycke J, Gunnarsson M, Nilsson P, et al. Autologous Haematopoietic Stem Cell Transplantation for Aggressive Multiple Sclerosis: The Swedish Experience. J Neurol Neurosurg Psychiatry (2014) 85(10):1116-21. doi: 10.1136/jnnp-2013-307207

41. Nash RA, Hutton GJ, Racke MK, Popat U, Devine SM, Steinmiller KC, et al. High-Dose Immunosuppressive Therapy and Autologous HCT for Relapsing-Remitting MS. Neurology (2017) 88(9):842-52. doi: 10.1212/ WNL.0000000000003660

42. Curro D, Vuolo L, Gualandi F, Bacigalupo A, Roccatagliata L, Capello E, et al. Low Intensity Lympho-Ablative Regimen Followed by Autologous Hematopoietic Stem Cell Transplantation in Severe Forms of Multiple Sclerosis: A MRI-Based Clinical Study. Mult Scler (2015) 21(11):1423-30. doi: $10.1177 / 1352458514564484$

43. Mariottini A, Innocenti C, Forci B, Magnani E, Mechi C, Barilaro A, et al. Safety and Efficacy of Autologous Hematopoietic Stem-Cell Transplantation Following Natalizumab Discontinuation in Aggressive Multiple Sclerosis. Eur J Neurol (2019) 26(4):624-30. doi: 10.1111/ene.13866

44. Das J, Snowden JA, Burman J, Freedman MS, Atkins H, Bowman M, et al. Autologous Haematopoietic Stem Cell Transplantation as a First-Line Disease-Modifying Therapy in Patients With 'Aggressive' Multiple Sclerosis. Mult Scler (2021) 27(8):1198-204. doi: 10.1177/1352458520 985238

45. Burt RK, Loh Y, Cohen B, Stefoski D, Balabanov R, Katsamakis G, et al. Autologous Non-Myeloablative Haemopoietic Stem Cell Transplantation in Relapsing-Remitting Multiple Sclerosis: A Phase I/II Study. Lancet Neurol (2009) 8(3):244-53. doi: 10.1016/S1474-4422(09)70017-1

46. Atkins HL, Bowman M, Allan D, Anstee G, Arnold DL, Bar-Or A, et al. Immunoablation and Autologous Haemopoietic Stem-Cell Transplantation for Aggressive Multiple Sclerosis: A Multicentre Single-Group Phase 2 Trial. Lancet (2016) 388(10044):576-85. doi: 10.1016/S0140-6736(16)30169-6

47. Burt RK, Balabanov R, Burman J, Sharrack B, Snowden JA, Oliveira MC, et al. Effect of Nonmyeloablative Hematopoietic Stem Cell Transplantation vs Continued Disease-Modifying Therapy on Disease Progression in Patients With Relapsing-Remitting Multiple Sclerosis: A Randomized Clinical Trial. Jama (2019) 321(2):165-74. doi: 10.1001/jama.2018.18743

48. Burman J, Fox RJ. Autologous Hematopoietic Stem Cell Transplantation for MS: Safer Than Previously Thought. Neurology (2017) 88(22):2072-3. doi: 10.1212/WNL.0000000000003995

49. Burt RK, Han X, Quigley K, Helenowski IB, Balabanov R. Real-World Application of Autologous Hematopoietic Stem Cell Transplantation in 507 Patients With Multiple Sclerosis. J Neurol (2021) 11:1-14. doi: 10.1007/ s00415-021-10820-2

50. Murrieta-Alvarez I, Cantero-Fortiz Y, Leon-Pena AA, Olivares-Gazca JC, Priesca-Marin JM, Ruiz-Delgado GJ, et al. The 1,000th Transplant for Multiple Sclerosis and Other Autoimmune Disorders at the HSCT-Mexico Program: A Myriad of Experiences and Knowledge. Front Neurol (2021) 12:647425. doi: 10.3389/fneur.2021.647425

51. Boffa G, Massacesi L, Inglese M, Mariottini A, Capobianco M, Lucia M, et al. Long-Term Clinical Outcomes of Hematopoietic Stem Cell Transplantation in Multiple Sclerosis. Neurology (2021) 20:10.1212/ WNL.0000000000011461. doi: 10.1212/WNL.0000000000011461
52. Nicholas RS, Rhone EE, Mariottini A, Silber E, Malik O, Singh-Curry V, et al. Autologous Hematopoietic Stem Cell Transplantation in Active Multiple Sclerosis: A Real-World Case Series. Neurology (2021) 97(9):e890-901. doi: 10.1212/WNL.0000000000012449

53. Snowden JA, Badoglio M, Labopin M, Giebel S, McGrath E, Marjanovic Z, et al. Evolution, Trends, Outcomes, and Economics of Hematopoietic Stem Cell Transplantation in Severe Autoimmune Diseases. Blood Adv (2017) 1 (27):2742-55. doi: 10.1182/bloodadvances.2017010041

54. Majhail NS, Rizzo JD, Lee SJ, Aljurf M, Atsuta Y, Bonfim C, et al. Recommended Screening and Preventive Practices for Long-Term Survivors After Hematopoietic Cell Transplantation. Bone Marrow Transplant (2012) 47(3):337-41. doi: 10.1038/bmt.2012.5

55. DeFilipp Z, Duarte RF, Snowden JA, Majhail NS, Greenfield DM, Miranda JL, et al. Metabolic Syndrome and Cardiovascular Disease After Hematopoietic Cell Transplantation: Screening and Preventive Practice Recommendations From the CIBMTR and EBMT. Biol Blood Marrow Transplant (2016) 22(8):1493-503. doi: 10.1016/j.bbmt.2016.05.007

56. Alexander T, Greco R, Snowden JA. Hematopoietic Stem Cell Transplantation for Autoimmune Disease. Annu Rev Medicine Vol 72 (2021) 2021:72:215-28.doi: 10.1146/annurev-med-070119-115617

57. Mariottini A, De Matteis E, Muraro PA. Haematopoietic Stem Cell Transplantation for Multiple Sclerosis: Current Status. BioDrugs (2020) 34 (3):307-25. doi: 10.1007/s40259-020-00414-1

58. Mancardi GL, Sormani MP, Gualandi F, Saiz A, Carreras E, Merelli E, et al. Autologous Hematopoietic Stem Cell Transplantation in Multiple Sclerosis: A Phase II Trial. Neurology (2015) 84(10):981-8. doi: 10.1212/ WNL.0000000000001329

59. Mancardi GL, Sormani MP, Di Gioia M, Vuolo L, Gualandi F, Amato MP, et al. Autologous Haematopoietic Stem Cell Transplantation With an Intermediate Intensity Conditioning Regimen in Multiple Sclerosis: The Italian Multi-Centre Experience. Mult Scler (2012) 18(6):835-42. doi: $10.1177 / 1352458511429320$

60. Muraro PA, Martin R, Mancardi GL, Nicholas R, Sormani MP, Saccardi R. Autologous Haematopoietic Stem Cell Transplantation for Treatment of Multiple Sclerosis. Nat Rev Neurol (2017) 13(7):391-405. doi: 10.1038/ nrneurol.2017.81

61. Boffa G, Lapucci C, Sbragia E, Varaldo R, Raiola AM, Curro D, et al. Aggressive Multiple Sclerosis: A Single-Centre, Real-World Treatment Experience With Autologous Haematopoietic Stem Cell Transplantation and Alemtuzumab. Eur J Neurol (2020) 27(10):2047-55. doi: 10.1111/ ene. 14324

62. Muraro PA, Douek DC, Packer A, Chung K, Guenaga FJ, Cassiani-Ingoni R, et al. Thymic Output Generates a New and Diverse TCR Repertoire After Autologous Stem Cell Transplantation in Multiple Sclerosis Patients. J Exp Med (2005) 201(5):805-16. doi: 10.1084/jem.20041679

63. Muraro PA, Robins H, Malhotra S, Howell M, Phippard D, Desmarais C, et al. T Cell Repertoire Following Autologous Stem Cell Transplantation for Multiple Sclerosis. J Clin Invest (2014) 124(3):1168-72. doi: 10.1172/ JCI71691

64. Harris KM, Lim N, Lindau P, Robins H, Griffith LM, Nash RA, et al. Extensive intrathecal $\mathrm{T}$ cell renewal following hematopoietic transplantation for multiple sclerosis. JCI Insight (2020) 5(2):e127655. doi: 10.1172/ jci.insight. 127655

65. Karnell FG, Lin D, Motley S, Duhen T, Lim N, Campbell DJ, et al. Reconstitution of Immune Cell Populations in Multiple Sclerosis Patients After Autologous Stem Cell Transplantation. Clin Exp Immunol (2017) 189 (3):268-78. doi: 10.1111/cei.12985

66. Abrahamsson SV, Angelini DF, Dubinsky AN, Morel E, Oh U, Jones JL, et al. Non-myeloablative autologous haematopoietic stem cell transplantation expands regulatory cells and depletes IL-17 producing mucosal-associated invariant T cells in multiple sclerosis. Brain (2013) 136(Pt 9):2888-903. doi: 10.1093/brain/awt182

67. Darlington PJ, Touil T, Doucet JS, Gaucher D, Zeidan J, Gauchat D, et al. Diminished Th17 (Not Th1) Responses Underlie Multiple Sclerosis Disease Abrogation After Hematopoietic Stem Cell Transplantation. Ann Neurol (2013) 73(3):341-54. doi: 10.1002/ana.23784

68. Kurioka A, Ussher JE, Cosgrove C, Clough C, Fergusson JR, Smith K, et al. MAIT Cells are Licensed Through Granzyme Exchange to Kill Bacterially 
Sensitized Targets. Mucosal Immunol (2015) 8(2):429-40. doi: 10.1038/ mi.2014.81

69. Le Bourhis L, Martin E, Peguillet I, Guihot A, Froux N, Core M, et al. Antimicrobial Activity of Mucosal-Associated Invariant T Cells. Nat Immunol (2010) 11(8):701-8. doi: 10.1038/ni.1890

70. Treiner E, Duban L, Bahram S, Radosavljevic M, Wanner V, Tilloy F, et al. Selection of Evolutionarily Conserved Mucosal-Associated Invariant T Cells by MR1. Nature (2003) 422(6928):164-9. doi: 10.1038 /nature 01433

71. Gold MC, Cerri S, Smyk-Pearson S, Cansler ME, Vogt TM, Delepine J, et al. Human Mucosal Associated Invariant T Cells Detect Bacterially Infected Cells. PloS Biol (2010) 8(6):e1000407. doi: 10.1371/journal.pbio.1000407

72. Kjer-Nielsen L, Patel O, Corbett AJ, Le Nours J, Meehan B, Liu L, et al. MR1 Presents Microbial Vitamin B Metabolites to MAIT Cells. Nature (2012) 491 (7426):717-23. doi: 10.1038/nature11605

73. Dusseaux M, Martin E, Serriari N, Peguillet I, Premel V, Louis D, et al. Human MAIT Cells are Xenobiotic-Resistant, Tissue-Targeted, CD161hi IL17-Secreting T Cells. Blood (2011) 117(4):1250-9. doi: 10.1182/blood-201008-303339

74. Walker LJ, Kang YH, Smith MO, Tharmalingham H, Ramamurthy N, Fleming VM, et al. Human MAIT and CD8alphaalpha Cells Develop From a Pool of Type-17 Precommitted CD8+ T Cells. Blood (2012) 119 (2):422-33. doi: 10.1182/blood-2011-05-353789

75. Gherardin NA, Souter MN, Koay HF, Mangas KM, Seemann T, Stinear TP, et al. Human Blood MAIT Cell Subsets Defined Using MR1 Tetramers. Immunol Cell Biol (2018) 96(5):507-25. doi: 10.1111/imcb.12021

76. Arruda LCM, de Azevedo JTC, de Oliveira GLV, Scortegagna GT, Rodrigues ES, Palma PVB, et al. Immunological Correlates of Favorable Long-Term Clinical Outcome in Multiple Sclerosis Patients After Autologous Hematopoietic Stem Cell Transplantation. Clin Immunol (2016) 169:4757. doi: 10.1016/j.clim.2016.06.005

77. Healey KM, Pavletic SZ, Al-Omaishi J, Leuschen MP, Pirruccello SJ, Filipi ML, et al. Discordant Functional and Inflammatory Parameters in Multiple Sclerosis Patients After Autologous Haematopoietic Stem Cell Transplantation. Mult Scler (2004) 10(3):284-9. doi: 10.1191/ $1352458504 \mathrm{~ms} 1022 \mathrm{oa}$

78. Carreras E, Saiz A, Marin P, Martinez C, Rovira M, Villamor N, et al. CD34+ Selected Autologous Peripheral Blood Stem Cell Transplantation for Multiple Sclerosis: Report of Toxicity and Treatment Results at One Year of Follow-Up in 15 Patients. Haematologica (2003) 88(3):306-14. doi: 10.1016/S1083-8791(03)80148-9

79. Larsson D, Akerfeldt T, Carlson K, Burman J. Intrathecal Immunoglobulins and Neurofilament Light After Autologous Haematopoietic Stem Cell Transplantation for Multiple Sclerosis. Mult Scler (2020) 26(11):1351-9. doi: $10.1177 / 1352458519863983$

80. Tolf A, Fagius J, Carlson K, Akerfeldt T, Granberg T, Larsson EM, et al. Sustained Remission in Multiple Sclerosis After Hematopoietic Stem Cell Transplantation. Acta Neurol Scand (2019) 140(5):320-7. doi: 10.1111/ ane. 13147

81. Darlington PJ, Stopnicki B, Touil T, Doucet JS, Fawaz L, Roberts ME, et al. Natural Killer Cells Regulate Th17 Cells After Autologous Hematopoietic Stem Cell Transplantation for Relapsing Remitting Multiple Sclerosis. Front Immunol (2018) 9:834. doi: 10.3389/fimmu.2018.00834

82. Choi SR, Howell OW, Carassiti D, Magliozzi R, Gveric D, Muraro PA, et al. Meningeal inflammation plays a role in the pathology of primary progressive multiple sclerosis. Brain (2012) 135(Pt 10):2925-37. doi: 10.1093/brain/ aws 189

83. Howell OW, Reeves CA, Nicholas R, Carassiti D, Radotra B, Gentleman SM, et al. Meningeal inflammation is widespread and linked to cortical pathology in multiple sclerosis. Brain (2011) 134(Pt 9):2755-71. doi: 10.1093/brain/ awr182

84. Corcione A, Aloisi F, Serafini B, Capello E, Mancardi GL, Pistoia V, et al. BCell Differentiation in the CNS of Patients With Multiple Sclerosis. Autoimmun Rev (2005) 4(8):549-54. doi: 10.1016/j.autrev.2005.04.012

85. Cencioni MT, Mattoscio M, Magliozzi R, Bar-Or A, Muraro PA. B cells in multiple sclerosis - from targeted depletion to immune reconstitution therapies. Nat Rev Neurol (2021) 17(7):399-414. doi: 10.1038/s41582-02100498-5
86. Bar-Or A, Fawaz L, Fan B, Darlington PJ, Rieger A, Ghorayeb C, et al. Abnormal B-Cell Cytokine Responses a Trigger of T-Cell-Mediated Disease in MS? Ann Neurol (2010) 67(4):452-61. doi: 10.1002/ana.21939

87. Gattinoni L, Zhong XS, Palmer DC, Ji Y, Hinrichs CS, Yu Z, et al. Wnt Signaling Arrests Effector T Cell Differentiation and Generates CD8+ Memory Stem Cells. Nat Med (2009) 15(7):808-13. doi: 10.1038/nm.1982

88. Gattinoni L, Ji Y, Restifo NP. Wnt/beta-Catenin Signaling in T-Cell Immunity and Cancer Immunotherapy. Clin Cancer Res (2010) 16 (19):4695-701. doi: 10.1158/1078-0432.CCR-10-0356

89. Gattinoni L, Lugli E, Ji Y, Pos Z, Paulos CM, Quigley MF, et al. A Human Memory T Cell Subset With Stem Cell-Like Properties. Nat Med (2011) 17 (10):1290-7. doi: 10.1038/nm.2446

90. Ahmed R, Roger L, Costa Del Amo P, Miners KL, Jones RE, Boelen L, et al. Human Stem Cell-Like Memory T Cells Are Maintained in a State of Dynamic Flux. Cell Rep (2016) 17(11):2811-8. doi: 10.1016/j.celrep. 2016.11.037

91. Cieri N, Oliveira G, Greco R, Forcato M, Taccioli C, Cianciotti B, et al. Generation of Human Memory Stem T Cells After Haploidentical T-Replete Hematopoietic Stem Cell Transplantation. Blood (2015) 125(18):2865-74. doi: 10.1182/blood-2014-11-608539

92. Yasuda K, Takeuchi Y, Hirota K. The Pathogenicity of Th17 Cells in Autoimmune Diseases. Semin Immunopathol (2019) 41(3):283-97. doi: 10.1007/s00281-019-00733-8

93. Akondy RS, Monson ND, Miller JD, Edupuganti S, Teuwen D, Wu H, et al. The Yellow Fever Virus Vaccine Induces a Broad and Polyfunctional Human Memory CD8+ T Cell Response. J Immunol (2009) 183(12):7919-30. doi: 10.4049/jimmunol.0803903

94. Fuertes Marraco SA, Soneson C, Cagnon L, Gannon PO, Allard M, Abed Maillard S, et al. Long-Lasting Stem Cell-Like Memory CD8+ T Cells With a Naive-Like Profile Upon Yellow Fever Vaccination. Sci Transl Med (2015) 7 (282):282ra48. doi: 10.1126/scitranslmed.aaa3700

95. Biasco L, Scala S, Basso Ricci L, Dionisio F, Baricordi C, Calabria A, et al. In Vivo Tracking of T Cells in Humans Unveils Decade-Long Survival and Activity of Genetically Modified T Memory Stem Cells. Sci Transl Med (2015) 7(273):273ra13. doi: 10.1126/scitranslmed.3010314

96. Oliveira G, Ruggiero E, Stanghellini MT, Cieri N, D’Agostino M, Fronza R, et al. Tracking Genetically Engineered Lymphocytes Long-Term Reveals the Dynamics of T Cell Immunological Memory. Sci Transl Med (2015) 7 (317):317ra198. doi: 10.1126/scitranslmed.aac8265

97. Abdelsamed HA, Zebley CC, Nguyen H, Rutishauser RL, Fan Y, Ghoneim HE, et al. Beta Cell-Specific CD8(+) T Cells Maintain Stem Cell MemoryAssociated Epigenetic Programs During Type 1 Diabetes. Nat Immunol (2020) 21(5):578-87. doi: 10.1038/s41590-020-0633-5

98. Turtle CJ, Swanson HM, Fujii N, Estey EH, Riddell SR. A Distinct Subset of Self-Renewing Human Memory CD8+ T Cells Survives Cytotoxic Chemotherapy. Immunity (2009) 31(5):834-44. doi: 10.1016/j.immuni. 2009.09.015

99. Neuenhahn M, Busch DH. The Quest for CD8+ Memory Stem Cells. Immunity (2009) 31(5):702-4. doi: 10.1016/j.immuni.2009.10.002

100. Lee YJ, Park JA, Kwon H, Choi YS, Jung KC, Park SH, et al. Role of Stem Cell-Like Memory T Cells in Systemic Lupus Erythematosus. Arthritis Rheumatol (2018) 70(9):1459-69. doi: 10.1002/art.40524

101. Blanco P, Ueno H, Schmitt N. T Follicular Helper (Tfh) Cells in Lupus: Activation and Involvement in SLE Pathogenesis. Eur J Immunol (2016) 46 (2):281-90. doi: 10.1002/eji.201545760

102. Cianciotti BC, Ruggiero E, Campochiaro C, Oliveira G, Magnani ZI, Baldini $\mathrm{M}$, et al. CD4+ Memory Stem T Cells Recognizing Citrullinated Epitopes Are Expanded in Patients With Rheumatoid Arthritis and Sensitive to Tumor Necrosis Factor Blockade. Arthritis Rheumatol (2020) 72(4):565-75. doi: 10.1002/art.41157

103. Burt RK, Muraro PA, Farge D, Oliveira MC, Snowden JA, Saccardi R, et al. New Autoimmune Diseases After Autologous Hematopoietic Stem Cell Transplantation for Multiple Sclerosis. Bone Marrow Transplant (2021) 56 (7):1509-17. doi: 10.1038/s41409-021-01277-y

104. Ljungman P, Lewensohn-Fuchs I, Hammarstrom V, Aschan J, Brandt L, Bolme P, et al. Long-Term Immunity to Measles, Mumps, and Rubella After Allogeneic Bone Marrow Transplantation. Blood (1994) 84(2):657-63. doi: 10.1182/blood.V84.2.657.bloodjournal842657 
105. Pauksen K, Duraj V, Ljungman P, Sjolin J, Oberg G, Lonnerholm G, et al. Immunity to and Immunization Against Measles, Rubella and Mumps in Patients After Autologous Bone Marrow Transplantation. Bone Marrow Transplant (1992) 9(6):427-32.

106. Colton H, Greenfield DM, Snowden JA, Miller PDE, Morley NJ, Wright J, et al. Long-Term Survivors Following Autologous Haematopoetic Stem Cell Transplantation Have Significant Defects in Their Humoral Immunity Against Vaccine Preventable Diseases, Years on From Transplant. Vaccine (2021) 39(34):4778-83. doi: 10.1016/j.vaccine.2021.07.022

107. Cordonnier C, Einarsdottir S, Cesaro S, Di Blasi R, Mikulska M, Rieger C, et al. Vaccination of Haemopoietic Stem Cell Transplant Recipients: Guidelines of the 2017 European Conference on Infections in Leukaemia (ECIL 7). Lancet Infect Dis (2019) 19(6):e200-12. doi: 10.1016/S1473-3099 (18)30600-5

108. Miller PDE, de Silva TI, Leonard H, Anthias C, Hoschler K, Goddard K, et al. A Comparison of Viral Microneutralization and Haemagglutination Inhibition Assays as Measures of Seasonal Inactivated Influenza Vaccine Immunogenicity in the First Year After Reduced Intensity Conditioning, Lymphocyte Depleted Allogeneic Haematopoietic Stem Cell Transplant. Vaccine (2019) 37(3):452-7. doi: 10.1016/j.vaccine.2018.11.061

109. Maneikis K, Sablauskas K, Ringeleviciute U, Vaitekenaite V, Cekauskiene $\mathrm{R}$, Kryzauskaite L, et al. Immunogenicity of the BNT162b2 COVID-19 mRNA Vaccine and Early Clinical Outcomes in Patients With Haematological Malignancies in Lithuania: A National Prospective Cohort Study. Lancet Haematol (2021) 8(8):e583-92. doi: 10.1016/ S2352-3026(21)00169-1

110. Dhakal B, Abedin S, Fenske T, Chhabra S, Ledeboer N, Hari P, et al. Response to SARS-CoV-2 Vaccination in Patients After Hematopoietic Cell Transplantation and CAR T-Cell Therapy. Blood (2021) 138(14):1278-81. doi: 10.1182/blood.2021012769

111. Harrington P, Doores KJ, Saha C, Saunders J, Child F, Dillon R, et al. Repeated Vaccination Against SARS-CoV-2 Elicits Robust Polyfunctional T Cell Response in Allogeneic Stem Cell Transplantation Recipients. Cancer Cell (2021) 39(11):1448-9. doi: 10.1016/j.ccell.2021.10.002.

112. Ciotti JR, Valtcheva MV, Cross AH. Effects of MS Disease-Modifying Therapies on Responses to Vaccinations: A Review. Mult Scler Relat Disord (2020) 45:102439. doi: 10.1016/j.msard.2020.102439

113. Sormani MP, Inglese M, Schiavetti I, Carmisciano L, Laroni A, Lapucci C, et al. Effect of SARS-CoV-2 mRNA vaccination in MS patients treated with disease modifying therapies. EBioMedicine (2021) 72:103581. doi: 10.2139/ ssrn. 3886420
114. Apostolidis SA, Kakara M, Painter MM, Goel RR, Mathew D, Lenzi K, et al. Cellular and Humoral Immune Responses Following SARS-CoV-2 mRNA Vaccination in Patients With Multiple Sclerosis on Anti-CD20 Therapy. Nat Med (2021) 27(11):1990-2001. doi: 10.1101/2021.06.23.21259389

115. Nash RA, Hutton GJ, Racke MK, Popat U, Devine SM, Griffith LM, et al. High-Dose Immunosuppressive Therapy and Autologous Hematopoietic Cell Transplantation for Relapsing-Remitting Multiple Sclerosis (HALTMS): A 3-Year Interim Report. JAMA Neurol (2015) 72(2):159-69. doi: 10.1001/jamaneurol.2014.3780

116. Cohen JA, Baldassari LE, Atkins HL, Bowen JD, Bredeson C, Carpenter PA, et al. Autologous Hematopoietic Cell Transplantation for TreatmentRefractory Relapsing Multiple Sclerosis: Position Statement From the American Society for Blood and Marrow Transplantation. Biol Blood Marrow Transplant (2019) 25(5):845-54. doi: 10.1016/j.bbmt.2019.02.014

Conflict of Interest: PM reports no conflict of interest. He discloses travel support and speaker honoraria from unrestricted educational activities organized by Novartis, Bayer HealthCare, Bayer Pharma, Biogen Idec, Merck Serono, and Sanofi Aventis. He also discloses consulting to Magenta Therapeutics and Jasper Therapeutics. JS declares honoraria for an advisory board from MEDAC, and as an IDMC member for a trial supported by Kiadis Pharma, all outside the submitted work. RG discloses honoraria for speaking from educational events supported by Biotest, Pfizer, and Magenta.

The remaining authors declare that the research was conducted in the absence of any commercial or financial relationships that could be construed as a potential conflict of interest.

Publisher's Note: All claims expressed in this article are solely those of the authors and do not necessarily represent those of their affiliated organizations, or those of the publisher, the editors and the reviewers. Any product that may be evaluated in this article, or claim that may be made by its manufacturer, is not guaranteed or endorsed by the publisher.

Copyright (C) 2022 Cencioni, Genchi, Brittain, de Silva, Sharrack, Snowden, Alexander, Greco and Muraro. This is an open-access article distributed under the terms of the Creative Commons Attribution License (CC BY). The use, distribution or reproduction in other forums is permitted, provided the original author(s) and the copyright owner(s) are credited and that the original publication in this journal is cited, in accordance with accepted academic practice. No use, distribution or reproduction is permitted which does not comply with these terms. 